\title{
Kırıkkale Tren Garı Üzerine Bazı Tespitler
}

Murat ÇERKEZ *

\section{$\ddot{O} z$}

Kırıkkale, İç Anadolu Bölgesi’nin Orta Kızılırmak bölümünde; kuzeyde Çankırı, kuzeydoğuda Çorum, doğuda Yozgat, güneydoğuda Kırşehir, batıda ise Ankara ile sınırlı bir ilimizdir. Cumhuriyet döneminde karşımıza çıkan modern kentlerin, özellikle endüstriyel gelişmeler sonucu ortaya çıktığı ve sanayinin temelini teşkil eden tesislerin etrafında geliştiği görülmektedir. Bu kapsamda Kırıkkale, Cumhuriyetin ilk yıllarında savunma sanayiinin güçlendirilmesi sebebi ile kurulan MKE fabrikaları yanı sıra konumuzu da teşkil eden tren garının inşası ile birlikte doğmuş ve şehir bu merkez etrafında gelişmiştir.

Kırıkkale Tren Garı, doğu-batı yönünde uzanan birbirine bitişik üç kütle halinde inşa edilmiştir. Yan kütleler tek, ortadaki ana kütle ise iki katlıdır ve diğerlerine göre hâkim bir görünüş sergiler. Bu tarz yapılarda ana kütlenin alt katındaki mekânlar idarî büro, bekleme salonu, gișe vb. hizmetlere ayrılırken üst katlar lojman olarak değerlendirilmiştir. Yan kütleler, yine idarî ofis olarak kullanılabildiği gibi depo, ambar, elektrik odası, güvenlik odası, dinlenme odası, fen memuru odası vb. fonksiyonlarda kullanılmıştır. Anadolu'da bu şekilde inşa edilmiş pek çok gar binası mevcuttur ve Kırıkkale Tren Garı da bunların tipik bir temsilcisi niteliğindedir.

Çalışmamızda bir Cumhuriyet Dönemi eseri olan gar binası plan, malzeme ve mimari özellikleri bakımından ayrıntılı bir şekilde tanıtılarak, şehrin gelişimindeki etkisi yanı sıra Anadolu Türk Mimarisi içerisindeki yeri ve önemi vurgulanacaktır.

Anahtar Kelimeler: Kırıkkale, Demiryolu, İstasyon Binaları, Mimari.

\section{Some Determinations On Kırıkkale Train Station}

\begin{abstract}
Kırıkkale, in the Central Kizılırmak region of the Central Anatolia Region; It is a city restricted to Çankırı in the north, Çorum in the northeast, Yozgat in the east, Kırşehir in the southeast and Ankara in the west. It is seen that the modern cities that emerged in the Republican era emerged especially as a result of industrial developments and the facilities that formed the basis of the industry. In this context, Kirıkkale was born in the early years of the Republic with the construction of the railway station, which also constitutes our location, as well as the MKE factories established due to the strengthening of the defense industry, and the city developed around this center.
\end{abstract}

Kirıkkale Train Station was built in three adjacent blocks extending in the east-west direction. The side blocks are single and the main block is two-layered and exhibit a dominant appearance compared to the others. In this type of buildings, the spaces on the lower floor of the main body are used for

* Doç.Dr. Ankara Hacı Bayram Veli Üniversitesi, Edebiyat Fakültesi, Sanat Tarihi Bölümü, Ankara-Türkiye. ORCID ID: 0000-0002-5685-9127 murat.cerkez@hbv.edu.tr 
administrative office, waiting room, box office, etc. But the upper floors were evaluated as lodging.Side block can be used as administrative office, as well as warehouse, electrical room, security room, rest room, science officer room etc. used in functions. There are many station buildings that built in this way in Anatolia and Kurıkkale Train Station is also a typical representative of these.

In our study, the station building, which is a work of the Republican Period, was introduced in detail in terms of plan, material and architectural features and its place in Anatolian Turkish Architecture as well as its impact on the development of the city will be emphasized.

Keywords: Kırıkkale, Railway, Station buildings, Architecture.

\section{GİRIŞ}

Kırıkkale, İç Anadolu Bölgesi’nin Orta Kızılırmak bölümünde yer alan ve kuzeyde Çankırı, kuzeydoğuda Çorum, doğuda Yozgat, güneydoğuda Kırşehir, batıda ise Ankara ile sınırlı bir ilimizdir (Harita:1). Konum itibariyle Anadolu’nun kuzeyini güneyine, batısını doğusuna bağlayan yol güzergâhı üzerinde önemli bağlantı noktalarından birini teşkil etmektedir. Nitekim Ankara'nın Çorum, Samsun, Artvin, Yozgat, Kırşehir, Kayseri ile olan karayolu bağlantısı yanı sıra Kayseri, Niğde, Adana, Sivas, Malatya, Erzincan, Erzurum, Kars ile olan demiryolu bağlantısı da Kırıkkale üzerinden sağlanmaktadır²(Harita:1).

1925’lerde 12 hanelik bir köy iken 1929'da Belediyelik, 1944 yılında da ilçe olan Kırıkkale, küçük bir kasaba görünümünü almış; uzun yıllar Ankara’ya bağlı iken 21 Haziran 1989 tarih ve 3578 Sayılı yasa gereğince merhum Cumhurbaşkanı Turgut Özal (Başbakan iken) tarafından yapılan törenle İl statüsüne kavuşmuştur³.

Şehirlerin tarihi geçmişlerine bakıldığında Cumhuriyet döneminde ve günümüze yakın tarihlerde kurulan modern şehirlerin çoğunlukla sanayileşmeye bağlı olarak ortaya çıktığ1 görülmektedir ${ }^{4}$. Kurtuluş Savaşı'ndan sonraki gelişen süreçte savunma sanayiinin ne denli önemli olduğunun bilincinde olan yöneticiler tarafından ilk planlı dönemde sanayileşmenin ve dolayısıyla savunma sanayiinin devlet politikası halinde geliştirilmesi öngörülmüş; bu kapsamda 1921 yılında "Askerî Fabrikalar Umum Müdürlügüü kurulmuştur ${ }^{5}$. Savunma sanayiinin gelişmesi için Kırıkkale’de entegre bir silah sanayiinin kurulması hususu, ilk kez İzmir İktisat Kongresi’nde ele alınmış, bu görüş ve kararlar doğrultusunda başlatılan çalışmalar sonucu; 1924'de Ankara Hafif Silah ve Top Tamir

2-Kırıkkale’nin karayolu ve demiryolu ulaşım bağlantısı hakkında ayrıntılı bilgi için bkz., Yusuf Gülyazı, Kırıkkale Şehir Coğrafyası (Ondokuz Mayıs Üniversitesi Sosyal Bilimler Enstitüsü Coğrafya Anabilim Dalı yayınlanmamış Yüksek Lisans Tezi), Samsun 2004, s.77-86.

3-Beşir Atalay, Sanayileşme ve Sosyal Değişme (Kırıkkale Araştırması), DPT, Ankara 1983, s.61, 69-70;Tarih İçinde Kırıkkale, Kırıkkale Belediyesi Yayınları, Kırıkkale 2008, s.201-202; Serap Göre-S.Ebru Ekici-Metin Atar, Kırıkkale Kültür ve Turizm Envanteri, Kırıkkale Valiliği Yayınları, Kırıkkale 2013, s.28-29; http://www.kirikkale. gov.tr/tarihce (E. T: 02.05.2020).

4-Atalay, a.g.e., s.156.

5-https://www.mkek.gov.tr/tr/page.aspx?id=13(Erişim Tarihi: 21.03 .2020 ). 
Atölyeleri, Fişek ve Marangoz Fabrikaları, 1928'de Kırıkkale Pirinç Fabrikası, 1928'de Kırıkkale Kuvvet Merkezi, 1929'da Kırıkkale Mühimmat Fabrikası, 1931'de Ankara Kayaş Kapsül Fabrikası, 1931'de Kırıkkale Çelik Fabrikası, 1935'de Ankara Gaz Maskesi üretimi için Mamak Gaz Maske Fabrikası, 1936'da Kırıkkale Barut, Tüfek ve Top Fabrikaları tesis edilmiştir'. Bu fabrikalar, kuruluşundan 1950'ye kadar "Askerî Fabrikalar" adı ile anılmış, daha sonra Sanayi Bakanlığı’na bağlı bugünkü Makine ve Kimya Endüstrisi Kurumu’nun temelini oluşturmuştur ${ }^{7}$. Bu bağlamda Kırıkkale, Cumhuriyet dönemi savunma sanayiine bağlı olarak kurulmuş ve gelişmiş bir şehir karakteri sergilemektedir

Kronoloji itibariyle Kırıkkale çevresinin tarihi geçmişi çok eskilere dayanmakla birlikte ${ }^{9}$ kent merkezi bir Cumhuriyet şehri olarak belirdiğinden Kırıkkale’ye bağlı ilçeler mimari miras bakımından daha zengin bir dokuya sahip iken ${ }^{10}$ şehir merkezindeki en önemli yapı konumuzu da teşkil eden tren garıdır.

Endüstriyel gelişmeler sonucu ortaya çıkan modern kentlerin şekillenmesinde kuşkusuz ki demir yollarının çok büyük önemi bulunmaktadır. Nitekim Richard Trevithick tarafından 1804 yılında ilk lokomotifin icad $1^{11}$ ile birlikte demiryolu ulaşımı çalışmaları büyük bir ivme kazanmıştır. George Stephenson tarafından 1814'te yapılan Rocket adlı lokomotif ilk kez İngiltere'de 18 Eylül 1825’te Stockton ile Darlington arasında sefer yapmıştır $^{12}$. 1825 yılında İngiltere'de ilk yolcu trenlerinin çalışmaya başlamasıyla birlikte, demiryolu güzergâhı üzerinde yolcuların bekleme ve korunma ihtiyaçlarını karşılayacak

6-Atalay, a.g.e., s.66-67; https://www.mkek.gov.tr/tr/page.aspx?id=13 (Erişim Tarihi: 21.03.2020).

7-Aydoğan Köksal, "Kızllırmak Doğusunda Ankara'nın Üç İlçe Merkezi”, Ankara Üniversitesi DTCF Coğrafya Araştırmaları Dergisi, Sayı: 3, Ankara 1962, s.171.

8-Atalay, a.g.e., s.61-87, 156; Gülyazı, a.g.t., s.19.

9-Kırıkkale’nin tarihi gelişimi ve coğrafyası hakkında ayrıntılı bilgi için bkz., Köksal, a.g.m., s.169-186; Mecit Yıldırım, Tarihte Kırıkkale, Öğretmenler Matbaası, Ankara 1966; Erdoğan Aslıüce, Her Yönüyle Kırlkkale, Emel Matbaacılık, Kırıkkale 1974; Atalay, a.g.e., 1983; Mehmet Pehlivanlı,Kırıkkale Çevre Incelemesi, Cemiloğlu Yayınları, Ankara 1986; aynı yazar, Kırıkkale, Genişletilmiş 1l. Baskı, Ankara 1992; Ömer Demir-A. Vural Örsdemir-Yakup Altın, Her Yönüyle Kırıkkale, Kırıkkale 1997; Ahmet Kankal, "Kırıkkale Tarihine Dair Araştırmalar I: İskân”, Osmanlı Tarihi Araştırmaları Merkezi Dergisi (OTAM), S.9, Ankara 1998, s.225-239; Kırıkkale Il Yıllı̆̆l, 1999; Yakup Altın, Bir Cumhuriyet Şehri Kırıkkale, Kırıkkale Valiliği Yayınları, Devran Matbaacılık, Ankara 2002; Gülyazı, a.g.t., 2004; Ercan Vural, Kırıkkale Şehri’nin Cumhuriyetten Günümüze Mekânsal Gelişimi (İstanbul Üniversitesi Sosyal Bilimler Enstitüsü Coğrafya Anabilim Dalı yayınlanmamış Yüksek Lisans Tezi), İstanbul 2018.

10-Kırıkkale çevresindeki mimari eserlere yönelik başlıca çalışmalar için bkz., Yağmur Saluk, Kırıkkale-Keskin 'in Kültür Mirası Orta Anadolu'da Bir Belgeleme ve Koruma Çalışması, Literatür Yayınları, İstanbul 2016; Damla Özgür, Kırıkkale'de Türk Devri Mimari Eserleri (Gazi Üniversitesi Sosyal Bilimler Enstitüsü Sanat Tarihi Anabilim Dalı yayınlanmamış Yüksek Lisans Tezi), Ankara 2019; Elif Tosun, Kırıkkale Keskin İlçesindeki Türk Mimari Eserleri (Ankara Hacı Bayram Veli Üniversitesi Sosyal Bilimler Enstitüsü Sanat Tarihi Anabilim Dalı yayınlanmamış Yüksek Lisans Tezi), Ankara 2019.

11-Serhan Yücel-Murat Taşar, "Demiryolunun Stratejik Önemi ve Erken Cumhuriyet Döneminde Demiryolu Siyaseti”, Vakanüvis-Uluslararası Tarih Araştırmaları Dergisi/International Journal of Historical Researches, Y.1, No.1, Mart 2016, s.297.

12-Sadi Borak, “Demiryollarının Tarihi”, Hayat Tarih Mecmuası, S.12 (98), 1969, s.82; Mehmet Özdemir, "Tren Gelir, Hoş Gelir, Kara Trenin Hikâyesi”, Anatolia: Turizm Araştırmaları Dergisi, C.23, S.1, 2012, s.118. 
istasyon binalarının yapımına gereksinim duyulmuştur ${ }^{13}$. Modern anlamda ilk demiryolu İngiltere'de Liverpool ve Manchester arasında, Amerika'da ise Baltimore ve Ohio arasında inşa edilmiştir. Bu kapsamda, dünyadaki ilk istasyon binalarının 1830 yılında inşa edilen İngiltere'deki Crown Street ile Amerika Baltimore'daki Mount Clare istasyon binası olduğu bilinmektedir ${ }^{14}$.

19. yüzyılın en önemli stratejik araçlarından biri olan demiryolları, önce kitle ulaşımı ve nakliyede kullanılmış, daha sonra sömürge siyaseti güden güçlerin vazgeçemediği bir araca dönüşerek kısa sürede dünyanın birçok bölgesinde demiryolları inşa edilmiştir ${ }^{15}$.

Ekonomi ve sanayileşmede demiryolunun önemini çok iyi kavrayan ve bunu büyük bir fırsata dönüştüren emperyalist batı ülkeleri için Osmanlı toprakları da çok cazip bir merkezdi ve burada geniş nüfuz alanları elde etmenin en etkili yolu demiryolu yapımından geçmekteydi ${ }^{16}$. Öte yandan İngilizlerin sömürgeleri olan Hindistan'a ulaşabilmesinin en kolay çözümü de yine demiryolu idi ve bu kapsamda Osmanlı coğrafyasında ilk olarak İngilizler tarafından 1856 yılında Mısır'daki İskenderiye-Kahire demiryolu hattı ulaşıma açılmıştır ${ }^{17}$. Osmanlılar da zaman içerisinde Batıdaki bu gelişmeleri takip etmiş, büyük bir ivme kazanan demiryolu sisteminin, ulaşım yanı sıra ekonomi, üretim, askerî ve siyasi alanda birçok probleme çözüm olacağını kavramıştı. Özellikle Sultan Abdülmecit, Sultan Abdülaziz ve Sultan II. Abdülhamit dönemlerinde devletin önemli bir politikası haline gelmiştir $^{18}$. Ancak o dönem itibariyle demiryolu yatırımlarını finanse edecek yeterli bütçe ve bu işi yapabilecek deneyimli teknik elemanın bulunmayışı, Hicaz müstesna olmak üzere Osmanlı demiryolları imtiyazlarının tamamı ile İngiliz, Alman ve Fransız şirketlerine verilmesine yol açmıştır ${ }^{19}$. Nitekim Anadolu'daki ilk demiryolu çalışmaları da Sultan Abdülaziz hamiliğinde İngiliz gruba verilen imtiyaz kapsamında 22 Eylül 1856'da temeli atılan ve ${ }^{1866}$ 'da işletmeye açılan İzmir-Aydın hattı ile başlamış ${ }^{20}$ ve sonrasında hızla devam etmiştir. Sultan II. Abdülhamit, iletişim ve ulaşım alanına yapılacak yatırımın iç ve dış tehditlerin bertaraf edilmesinde önemli bir yeri olduğunun farkına varmış, tesis ettiği telgraf hatları ve demiryolu ağları ile merkezi otoriteyi güçlendirmeye çalışmıştır ${ }^{21}$. En fazla demiryolu inşasının Sultan II. Abdülhamit (1876-1909) döneminde gerçekleştirildiği

13-Selen Durak, “19. Yüzyılda Geniş Açıklıklı Çatı Strüktürlerinin Gelişiminde Demiryolu İstasyon Binalarının Önemi”, 6. Ulusal Çatı ve Cephe Sempozyumu, Uludağ Üniversitesi Mühendislik ve Mimarlık Fakültesi-Görükle Kampüsü-Bursa, 12-13 Nisan 2012, s.2.

14-Durak, a.g.m., s.2.

15-Yücel-Taşar, a.g.m.,s.336.

16-İsmail Yıldırım, Cumhuriyet Döneminde Demiryolları, Atatürk Araştırma Merkezi Yayınları, Ankara 2001, s.6; Murat Özyüksel, Osmanlı Imparatorluğunda Nüfuz Mücadelesi, Anadolu ve Bağdat Demiryolları, Türkiye İş Bankası Kültür Yayınları, İstanbul 2013, s.7.

17-Özyüksel, a.g.e., s.7.

18-Metin Hülagü, “Cumhuriyet Öncesi Osmanlı Demiryollarına Genel Bir Bakış”, Cumhuriyet Döneminde Demiryolları Sempozyumu, 18 Aralık 2008, Atatürk Araştırma Merkezi Yayınları, Ankara 2010, s.26.

19-Hülagü, a.g.m., s.27; Özyüksel, a.g.e., s.7.

20-Vahdettin Engin, Rumeli Demiryolları, Eren Yayıncılık, İstanbul 1993, s.39.

21-Hülagü, a.g.m., s.37. 
görülmektedir.

Cumhuriyet öncesinde ülkede tamamı yabancı sermaye ile inşa edilmiş $4112 \mathrm{~km}$ demiryolu bulunmaktayd ${ }^{22}$. İmparatorluk sonrası yabancı sermaye ile inşa edilen bu hatlar yeni Cumhuriyet'e kalmış, hatların bir kısmı milli mücadele yıllarında, bir kısmı da ilerleyen yıllarda satın alınarak millileștirilmiştir²3.

Anadolu'da Milli Mücadele başlarında; Anadolu Demiryolu, Bağdat Demiryolu, MersinAdana Demiryolu, İzmir-Aydın Demiryolu, İzmir-Afyon Demiryolu, İzmir-Bandırma ve Mudanya-Bursa demiryolları bulunmaktayd ${ }^{24}$. Osmanlı'dan kalan demiryollarının büyük bir kısmı batı bölgelerinde yer aldığ ile bağlantısını sağlamak amacı ile öncelikle Ankara-Sivas ve Samsun-Sivas hatlarının inşasına karar verilmiştir. 23 Mart 1924 tarih ve 449 sayılı kanunla bu hatların beş senede tamamlanması için 65 milyonluk ödenek ayrılmış ve her iki hattın inşasına Ankara ve Samsun'dan başlanmıştır ${ }^{25}$.

Kırıkkale’nin de üzerinde yer aldığ Anadolu'yu birbirine bağlayan bu hat aynı zamanda askerî bir fonksiyon da üstlenmiştir. 380 kilometrelik Ankara-Kayseri ve 222 kilometrelik Kayseri-Sivas etaplarından oluşan hat; Ankara-Yahşihan-Yerköy-Kayseri ve Şarkışla yoluyla Sivas’a ulaşıyordu. Hat üzerinde 23 tanesi Ankara-Kayseri ve 3 tanesi de Kayseri-Sivas arasında olmak üzere 26 adet tünel yapılmıştır $^{26}$. Türk müteahhitler tarafından tesis edilen bu hat 1924 yılı bütçesinden ayrılan ödenekle devam etmiş, Ankara-Yahşihan arasındaki 86 km'lik bölüm 17 Nisan 1925 'te, Yahşihan-Yerköy arasındaki bölüm 20 Kasım 1925'te tamamlanmış, tamamı ise 30 Ağustos 1930 tarihinde açılmıştır ${ }^{27}$. Bu kapsamda Kırıkkale İstasyonu'nun da Yahşihan Garı̀ndan kısa bir süre sonra hizmete girdiği ve bundan sonraki süreçte "Ara İstasyon"28 niteliğinde önemli bir fonksiyon üstlendiği görülmektedir.

Çalışmamızda bir Cumhuriyet Dönemi eseri olan Kırıkkale Tren Garı plan, malzeme ve mimari özellikleri bakımından ayrıntılı bir şekilde tanıtılarak, şehrin gelişimindeki etkisi yanı sıra Anadolu Türk Mimarisi içerisindeki yeri ve önemi vurgulanacaktır.

22-Yıldırım, Cumhuriyet Döneminde..., s.6; Özyüksel, a.g.e., s.36-38.

23-Yıldırım, Cumhuriyet Döneminde..., s.6; Özyüksel, a.g.e., s.40-47.

24-Mukaddes Arslan, "Milli Mücadele Tarihimizde Demiryolları ve Demiryolcular”, Cumhuriyet Döneminde Demiryolları Sempozyumu, 18 Aralık 2008, Atatürk Araştırma Merkezi Yayınları, Ankara 2010, s.49.

25-Oğuz Uçar, 1923-1933 Yıllarında T.C. Devleti Demiryolları Politikası (Ankara Üniversitesi Türk İnkılap Tarihi Enstitüsü yayınlanmamış Yüksek Lisans Tezi), Ankara 1989, s.25; Efdal As, Cumhuriyet Dönemi Ulaşım Politikaları (1923-1960), (Dokuz Eylül Üniversitesi Atatürk İlkeleri ve İnkılâp Tarihi Enstitüsü yayınlanmamış Doktora Tezi), İzmir 2006, s.98.

26-Yücel-Taşar, a.g.m., s.332.

27-Yıldırım, Cumhuriyet Döneminde..., s.75-77; Yücel-Taşar, a.g.m., s.332-333; As, a.g.t., s.98.

28-Trenlerin her iki yönde de geliş gidişine imkan sağlayan, aynı anda olabildiğince çok trenin hareket edebilmesine uygun hatların banalize edildiği istasyonlara verilen addır. Bilgi için bkz., Haştemoğlu, a.g.t., s.46. 


\section{KIRIKKALE TREN GARI}

Eser, Fabrikalar Mahallesi’nde Millet Bulvarı'nın güney yanındaki düz bir alan üzerinde ${ }^{29}$ yer almaktadır (Res.1). Ankara Kültür ve Tabiat Varlıklarını Koruma Kurulu'nun 30.03.2007 tarih ve 2254 sayılı kararı ile tescil edilmiştir.

Kuzeyinde şehrin ana arter niteliğini taşıyan ve Ankara-Samsun karayoluna kadar istasyona dik uzanan Atatürk Bulvarı, doğusunda şehre kimliğini kazandıran Kaletepe, güneydoğusunda MKE Pirinç Fabrikası, güneyinde MKE Mühimmat Fabrikaları, güneybatısında MKE Ağır Silah-Çelik Fabrikası ile MKE Barut Fabrikası yer almaktadır. Halen mevcut durum itibariyle Kırıkkale İl Emniyet Müdürlüğü, Kırıkkale Belediyesi ve Kırıkkale Adalet Sarayı da gar binasının yakın çevresine konumlanmış vaziyettedir.

İnşa tarihini belirten herhangi bir kitabesi bulunmamakla birlikte, kayıtlara geçmiş belgelerde ${ }^{30} 1925$ yılında inşa edildiği belirtilmektedir. Öte yandan üzerinde ayrıntıları ile duracağımız plan, malzeme ve mimari özellikleri de aynı döneme işaret etmektedir. İnşasından sonraki süreçte tarihini belirleyemediğimiz dönemlerde çeşitli müdahaleler görmüş, yetersiz kalması üzerine her iki yana doğru kısmen genişletilmiştir. Günümüzde sağlam vaziyette halen hizmete devam etmektedir.

Eser, mevcut durum itibariyle her biri dikdörtgen plana sahip birbirine bitişik üç kütle halinde uzanmaktadır (Çiz.1). Ortadaki ana kütle diğerlerine göre daha küçük bir bina olmakla birlikte iki katlı yapısı itibariyle hâkim görünüşlüdür. Doğudaki bina hepsinden daha geniştir ve ana yapı dikkate alındığında kuzeyde kısmen taşıntılı güneyde ise biraz içerlek bir kütleye sahiptir. Batı yandaki bina ise güneyde doğudaki bina ile aynı hizada uzanırken, kuzeyde ana kütleden biraz içerlektir. Güneyde istasyona paralel uzanan raylar ve peronlar, kuzeyde ise küçük ve dar bir avlusu vardır.

Halen mevcut durum böyle olmakla birlikte ulaşılabilen eski fotoğraflardan ve cephelerdeki izlerden yan kütlelerin zaman içerisinde çeşitli ilavelerle genişletildiği ve bir takım müdahalelerle günümüzdeki şeklini aldığı anlaşılmaktadır (Res.2). İstasyonun fonksiyon itibariyle ilk başlarda yeterli olduğu, ancak fabrikaların inşasıyla birlikte şehrin zaman içerisinde devamlı gelişerek nüfusun da artması üzerine yan kütlelerin ihtiyacı karşılayabilmek amacı ile genişletildiği yine eski fotoğraflardan ${ }^{31}$ belirlenebilmektedir (Res. 3-4). Müdahalelerin tarihleri tam kestirilemese de günümüzdeki halinin 1970’li yıllarda da aynı olduğu söz konusu fotoğraflardan anlaşılmakta ve ilk genişletme çalışmalarının inşasından kısa bir süre sonra yapıldığı tahmin edilmektedir ${ }^{32}$. Bu müdahaleler yeri

29-Yap1, 621 Ada ve 5 parselde yer almaktadır.

30-Demiryolları Mecmuası, Cumhuriyetin 10. Yılı Özel Sayısı, C.9, S.104/105, 29.X.1933, s.545.

31-Arşivini açarak fotoğrafları bizimle paylaşma nezaketi gösteren kıymetli Ahmet Yaman beyefendiye sonsuz teşekkürlerimi sunarım.

32-Çalışmayı yaptığımız sırada DDY arşivi tadilatta bulunduğundan eserle ilgili bilgi edinebileceğimiz herhangi bir arşiv vesikası temin edilememiştir. İncelemelerimiz esnasında gösterdikleri ilgi ve yardımlardan dolayı gar müdürlügüne sonsuz teşekkürlerimi sunarım. 
geldikçe ayrıntıları ile açıklanacaktır.

İnşa malzemesi kaba yonu-kesme taş, kiremit ve ahşaptır. Duvarlar kaba yonu ve kesme taşlarla yığma tekniğinde örülmüş, örtü sisteminde Marsilya tipi kiremitler, kapı ve pencere kanatları ile doğramalarında ise ahşap malzeme kullanılmıştır.

Cepheler, son derece sade görünüşlü olmakla birlikte kapı ve pencere açıklıkları ile kütlelerin köşe bağlantılarındaki vurgulu taş düzenlemesi bu masifliği kısmen gideren unsurlardır. Bütün duvarlar çimento harcı ile sıvanarak yüzeylerine sarı badana yapılmıștır (Res.1).

Ortadaki ana kütle üç, doğu ve batı yandaki kütleler ise iki kademeli bir görünüş sergiler. Ana kütle iki katlı yapısı ile diğerlerinden daha yüksek ve daha hâkim bir düzenlemeye sahiptir (Res.5). Birinci kademeyi teşkil eden alt kat hizmet binası, ikinci kademeyi teşkil eden üst kat ise lojman niteliğinde düzenlenmiştir. Kuzey ve güneye yönelen cephelerde birer balkon yer alır ve bunlar aynı zamanda her iki kademeyi birbirinden ayıran unsurlardır. Güneydeki balkon cephe boyunca uzanırken kuzeydeki balkon, cephenin batıya doğru yarısına kadar uzanır. Her iki balkon da betonarme kuruluşludur ve çubuk demirlerle yapılmış basit birer korkuluğa sahiptir. Üçüncü kademe Marsilya tipi kiremitle kaplı kırma çatılı örtü sisteminden ibarettir ve çatı uzantısı dört yönde de kısmen taşırılarak birer saçak oluşturulmuştur.

Cephelerde simetrik bir görünüş hâkimdir. Güney cephede kapı ve pencere açılıkları cephe eksenine göre simetrik bir düzenleme ile yerleştirilmiştir. Alt katta iki kenarda birer kapı, ortada ise bir pencere açıklığı mevcuttur. Hepsi de sivri kemerli bu açıklıklarda kısmen taşıntılı rüstik taşlar kullanılmış, sövelerde taşların bir büyük bir küçük alternatif dizilmesiyle bir hareketlilik kazandırılmış ve kemer kenarları biraz daha taşırılarak bir çerçeve teşkil edilmiştir. Ayrıca kemer üzengilerinden itibaren ön yüzü düz alt kısmı profilli birer korniş cephe boyunca uzanarak görünüşe zenginlik kazandırmıştır (Res.6). Kuzey cephede de aynı düzen tekrar edilmekle birlikte, farklı olarak batı kenara yakın konumla yan yana yerleştirilmiş kare biçimi iki küçük pencere açıklığı daha mevcuttur. Ayrıca bu cephede doğu yandaki kapı, diğerine göre daha geniş bir açıklığa sahiptir (Res.7). İkinci katta, güney cephede eksende boyuna dikdörtgen bir kapı açıklığı ile iki yanında eşit aralıklarla yerleştirilmiş boyuna dikdörtgen birer pencere açıllı̆̆ 1 görülmektedir (Res.5). Kuzey cephede ise doğu kenara yakın konumlu ve balkona irtibatlı bir kapı açıklığı ile eksende ve onun hemen batı yanında birer pencere açıklığı mevcuttur (Res.7).

Ana kütlenin doğu ve batı cepheleri, bitişik nizam diğer binalar nedeni ile tam seçilememekle birlikte, çatı seviyelerinden itibaren yükselen kısımlarında doğu cephede güney kenara yakın konumla bir, batı cephede ise eş aralıklı iki pencere açıklığı görülebilmektedir. Ancak, doğu cephede eski halinde iki pencere açıklığının mevcudiyeti tespit edilebilmekle birlikte, kuzey uçtaki pencerenin daha sonraki onarımlar sırasında kapatıldığı anlaşılmaktadır (Res.2). Bu pencereler de ikinci kattaki diğer pencerelerle aynı görünüşü yansıtmaktadır. Cephelerde bütün köşe bağlantıları rüstik taşlarla kısmen 
taşırılarak vurgulanmıştır. Ayrıca alt seviyedeki kapı ve pencere üzengileri hizasınca uzanan korniş ile aynı görünüşte bir silme, ana kütle duvarlarının üst kenarları boyunca binayı çepeçevre kuşatmaktadır (Res.7). Ana kütlenin aslî halini tamamen koruyarak günümüze ulaştığı eski fotoğraflardan anlaşılabilmektedir.

Doğu ve batı yandaki kütleler, alt kademesi beden duvarları, üst kademesi Marsilya tipi kiremitlerle kaplı örtü sisteminden ibaret iki kademeli bir yapıya sahiptir. Doğudaki kütle kırma çatı ile örtülü iken batıdaki kütlenin batıya bakan dar kenarı tepe mahyasına yakın bir hizada kırılarak yarım kırma çatı teşkil edilmiştir. Her iki kütle, cephe tasarımı, kapı ve pencere açıklıkları gibi unsurlar bakımından ana kütle ile benzer özellikler sergilemesinin yanı sıra düzen itibariyle desimetrik birer görünüş yansıtırlar.

Doğu yandaki binanın ilk inşasında, esasen kuzey-güney yönünde dikdörtgen planlı, çatısız küçük bir kütle halinde inşa edildiği, güney cephesinde şu an kapı olan açıklığın esasen bir pencere olduğu ve buradan itibaren kütlenin sona erdiği; bu kütlenin doğu cephesinde ise kuzey kenara yakın bir kapı ile güney kenara yakın bir pencere açıklı̆̆ının mevcudiyeti eski fotoğrafta açıkça görülebilmektedir (Res.2). Ancak bu ünite zaman içerisinde ihtiyaçlar çerçevesinde doğuya doğru genişletilerek günümüzdeki şeklini almıştır. Mevcut durum itibariyle doğudaki bina kütlesinin kuzey cephesinde dört kapı, iki pencere açıklığ (Res.8); güney cephesinde beş kapı, bir pencere; doğu cephesinde ise iki pencere açıklığ 1 (Res.1) görülmektedir. Tamamı da sivri kemerli ve cephe eksenine göre simetrik düzenli bu açıklıklardan, kuzeydeki pencerelerden biri doğu kenara, diğeri batı yandaki iki kapı açıklığının arasına; güney cephedeki tek pencere ise yine batı yandaki iki kapı açıklığının arasına yerleştirilmiştir. Pencere açılklılarına ait kemerlerin üst kenar hizaları kapı açıklıklarına göre biraz daha alçak seviyededir. Bu açıdan bakıldığında güney cephenin doğu kenarındaki mevcut kapı, pencerelerle aynı seviyede ve yaklaşık aynı genişlikte bir açıklığa sahiptir ve bu da daha önceleri pencere iken sonradan kapıya dönüştürülmüş olabileceğini düşündürmektedir. Doğu yandaki bu kütlenin, ana kütleden itibaren kuzeye doğru taşıntılı batı cephesinde enine dikdörtgen küçük bir pencere açıklığı daha mevcuttur (Res.7). Ana kütledeki kapı ve pencere üzengileri hizasınca uzanan korniş ile aynı görünüşte bir silme, bu kütlede de aynen tekrar edilmiş ve cephelere bir hareketlilik kazandırılmıştır. İlave kısımlardaki cephe düzenlemelerinin eserin aslî haline tamamen uygun yapıldığı da rahatlıkla anlaşılabilmektedir.

Batı yandaki bina kütlesinin de doğudaki gibi bazı ilavelerle genişletildiği yine eski fotoğraflardan tespit edilebilmektedir. Daha önceki halinde ana binaya bitişik olmak üzere yan yana üç açıklıklı bir yapıdan ibaret iken (Res.3) batıya doğru uzatılmış ve günümüzdeki şekline dönüştürülmüştür. Halen mevcut kütle cephe, kapı ve pencere düzenlemeleri bakımından diğerleriyle benzer özellikler sergilemekle birlikte bazı farklılıkları da mevcuttur. Kuzeyde üç kapı, üç pencere; güneyde dört kapı, üç pencere; batı cephede ise bir kapı açılığı görülmektedir. Kuzey cephedeki açıklıklardan doğuya doğru ilk üçü kapı diğerleri penceredir (Res.9). Güney cephede ise batıdan doğuya doğru bir pencere, üç kapı, bir pencere, bir kapı ve bir pencere şeklinde sıralanmaktadır (Res.10). Pencerelerden batı uçtaki boyuna, doğu uçtaki enine dikdörtgendir. Diğer kapı ve pencerelerin tamamı 
basık kemerli birer açıklığa sahiptir. Batı cephede ise eksene yerleşik boyuna dikdörtgen bir kapı açıklığı bulunmaktadır (Res.9). Kapı ve pencere açılılıklarına dikkatlice bakıldığında eserin genişletilmesinden başka zaman içerisinde çeşitli müdahalelere uğradığı anlaşılabilmektedir. Zira yapının diğer kütlelerindeki pencere açıklıklarına ait alt sövelerin önündeki profilli taşlar buradaki pencerelerde mevcut değildir ve onların yerine basit birer taş yerleştirilmiştir. Güney cephede özellikle doğu yandaki kapı açıklığı esasen bir bütün iken sonradan örülerek kapatılmış ve içerideki helâ ile irtibatlı bir pencere ve kapı açıklığına dönüştürülmüştür. Batı cephedeki kapı açıklığında da müdahale izleri açıkça görülmektedir. Burada yine önceki halinde profilli taşlarla kuşatılmış basık kemerli bir açıklık mevcutken sonradan örülmek suretiyle boyuna dikdörtgen yeni bir kapı açıklığı teşkil edilmiştir. Bu kütlede cephe kuruluşu ile kapı ve pencere açıklıklarındaki taşıntılı rüstik taşlar, diğer kütlelerdekilerle aynı görünüşü sergilemesine rağmen açıklıkların basık kemerli yapılması ve üzengi hizaları boyunca uzanan kornişin burada uygulanmaması dikkat çekici farklılıklar olarak belirmektedir.

İç mekânların aslî halleri ve taksimatı hakkında kesin bilgiler vermek pek mümkün görünmemektedir. Ancak fonksiyon bakımından yine aynı görevlere hizmet ettiği söylenebilir. Mevcut durum itibariyle ortadaki ana kütle yine iki katlı bir kuruluşa sahiptir. Alt katı idarî birimler, üst katı ise yine idarî büro ve kısmen lojman olarak kullanılmaktadır. Alt kat doğu-batı yönünde dikdörtgen bir kütleye sahiptir. Bu kütle öncelikle kendi içerisinde doğu-batı yönünde örülen bir ara duvarla iki üniteye ayrılmış, kuzeydeki ünite üç, güneydeki ünite ise iki bölüme ayrılmıştır. Güneydeki ünitelerin ikisi de doğu-batı yönünde dikdörtgen planlıdır ve batıdaki daha büyük olan hacim gar müdür yardımcısı odası (Res.11), diğeri güvenlik işlevi ile kullanılmaktadır. İdarî büro güney duvarda yer alan bir kapı ve pencere, güvenlik odası ise sadece kapı açıklığına sahiptir. Kuzeydeki mekânlardan yandakiler doğu-batı; ortadaki kuzey-güney yönünde dikdörtgen planlıdır ve onlardan biraz daha küçüktür. Batı yandaki bölüm esasen lojmanla irtibatlı merdiven evinden ibarettir, ancak kuzeybatı köşesine doğu-batı yönünde dikdörtgen planlı küçük ve dar bir helâ ünitesi yerleştirilmiştir (Res.12). Kuzeydeki bir kapı açıklı̆ı̆ndan girilen mekânda, merdiven kütlesi güney duvar ortasından itibaren, batı ve kuzey duvarlara bitişik olarak U şeklinde yükselmektedir. Helâ ünitesinin kapı açılığı güney duvarında eksenden biraz doğuya kaydırılarak yerleştirilmiştir. Kuzey duvarında da iki küçük pencere açıklığı mevcuttur. Diğer iki ünite aslında bir bütün olarak tasarlanmakla birlikte, kuzeye doğru uzanan bir duvarla ikiye ayrılmış ve bu duvarın kuzey kenarındaki boyuna dikdörtgen bir açıklıkla da irtibatları sağlanmıştır. Çalışanlar tarafından dinlenme ünitesi olarak kullanılan mekâna doğudaki bölümün ekseninde yer alan bir kapıdan girilmektedir, ayrıca ortadaki bölümün kuzey duvar eksenine de bir pencere açılı̆ğı yerleştirilmiştir.

Ana kütlenin üst katı üç oda, bir salon teşkiliyle lojman niteliğinde düzenlenmiş olmakla birlikte günümüzde hem lojman hem de idarî ofis olarak kullanılmaktadır (Res.13).

Doğu yandaki kütle, ana hatları ile kuzey-güney yönünde dikdörtgen planlı üç üniteye ayrılmıştır. Bu ünitelerden, ana kütleye bitişik olan batı yandaki hacim, aslında eski fotoğrafta (Res.2) yapının ilk halinde de mevcudiyeti görülebilen kütledir. Aslî halindeki 
taksimatını bilemediğimiz bu kütle, günümüzde kendi içerisinde birbiri ile irtibatlı olmak üzere kuzeyde iki, güneyde üç bölüme ayrılmıştır. Kuzeydeki bölümlerden batı yandaki doğu-batı yönünde dikdörtgen, doğu yandaki ise kuzey-güney yönünde dikdörtgen planlı küçük bir hacimdir. Burası da yine ana kütlenin kuzey yanında yer alan dinlenme mekânı gibi bir bütün olarak tasarlanmış, aynı tarz bir duvar ve kapı açılığı ile ikiye ayrılmış ve aynı fonksiyonla kullanılmıştır (Res.14). Küçük mekânın kuzey duvar ekseninde bir pencere, büyük mekânın kuzey duvarında doğu kenara yakın bir kapı ile batı duvarında küçük bir pencere açıklığı mevcuttur. Ayrıca burada güney duvarın doğu kenarına yakın konumla güney yandaki ünite ile irtibatlı boyuna dikdörtgen bir kapı açılığı daha vardır. Güney yandaki mekânlardan batı taraftaki kuzey-güney yönünde dikdörtgendir ve hem daha geniş hem de diğer ikisi ile aynı uzunluğa sahiptir. Doğu taraftaki bölümler ise arka arkaya yerleştirilmiş kuzeydeki doğu-batı, güneydeki kuzey-güney yönünde dikdörtgen planlı birer hacimdir. Batıdaki büyük mekân hareket memurluğu (Res.15), doğudaki ünitelerden güney yandaki vezne, bunun hemen kuzeyindeki küçük ünite ise bir hol niteliğinde kullanılmaktadır. Hareket memurluğu odasının doğu duvarının kuzey kenarına yakın konumla yerleştirilen bir kapı açılığından hole, holün güney duvar eksenindeki bir kapıdan da vezne ünitesine geçiş sağlanmaktadır. Holde kapılardan başka herhangi bir açıklık mevcut değildir. Hareket memurluğunun güney duvarında doğu kenara yakın bir kapı, vezne ünitesinin güney duvar ekseninde bir pencere ile doğu duvarında da doğu yandaki bekleme salonu ile irtibatlı büyük bir açıklık mevcuttur. Binanın eski halini gösteren fotoğraftan (Res.2) hareket memurluğunun güney duvarında yer alan kapıdan itibaren doğu yandaki ünitenin bu kütleden ibaret olduğunu, doğu cephede görülen pencere açılığıının vezne açıklığına dönüştürüldüğünü ve yine bu cephede görülen kapının da genişletmeler sırasında örülerek kapatıldığını söylemek mümkündür. Doğudaki kütlenin orta bölümü diğer ikisinden daha büyüktür. Halen bekleme salonu işlevi gören mekânın kuzey ve güney duvarında simetrik düzenli üçer kapı açıklığı ile batı duvarında gişe penceresi yer alır (Res.16). Mekânın kuzey doğu köşesi, yakın tarihlerde ince sunta levhalarla bölünerek küçük basit bir mescit teşkil edilmiştir. Doğu kenardaki ünite gar müdürlüğü olarak kullanılan bir hacimdir (Res.17). Güney duvarında batı kenara yakın bir kapı açıklığı ile bunun tam karşısında bir pencere ve doğu duvarında yine iki pencere açıklığı mevcuttur.

Batı yandaki kütle kendi içerisinde altı bölümlü bir düzenlemeye sahiptir. Birinci bölüm, en batıdaki kuzey-güney yönünde dikdörtgen planlı küçük mekândır ve elektrik odası olarak işlev görmektedir. Bu bölümün batı duvarında kapı, doğu ve güney duvarında ise birer pencere açıklığı yer alır. İkinci bölüm doğu-batı yönünde dikdörtgen planla uzanan büyük bir ünitedir ve ambar fonksiyonu ile kullanılmaktadır (Res.18). Kuzey ve güney duvarlarında simetrik düzenli basık kemerli üçer kapı açıklığı yer alır. Doğu duvarında eksene yerleşik enine dikdörtgen büyük bir pencere açılı̆̆ 1 ile bunun hemen kuzeyinde üçüncü ve dördüncü bölümlere geçiş sağlayan boyuna dikdörtgen bir kapı açıklığı görülür. Üçüncü ve dördüncü bölümler esasen tek bir hacimden ibaret olmakla birlikte kuzey ve güney duvarlarının yaklaşık ekseninde yer alan duvara bitişik birer ve tam ortaya yerleşik serbest konumlu bir ayak ile bölüntüye uğratılmıştır (Res.19). Bölüntülü bu iki odanın kuzey duvarlarında birer pencere yer alır. Batı yandaki odanın güney duvarında 
bir pencere daha mevcuttur. Doğu yandaki oda L şeması sergilemektedir. Bunun doğu yanında boyuna dikdörtgen planlı beşinci bölüm; güney yanında ise doğu-batı yönünde uzanan ve aynı zamanda beşinci bölümün güney duvarını da teşkil eden altıncı bölüm yer almaktadır. Beşinci bölümün kuzey duvarında bir pencere, batı duvarında eksenden biraz güneye kaydırılarak yerleştirilen ve dördüncü bölümle irtibatlı bir kapı ile bunun hemen kuzeyinde bir pencere açılılı̆̆ görülür. Üç, dört ve beşinci bölümlerin dişa açılan herhangi bir kapısı yoktur, bu mekânlara irtibat yalnızca ikinci bölümün doğu duvarındaki kapıdan sağlanmaktadır. Dolayısı ile bu ünitelerin bir bütün olarak tasarlandı̆̆ı ancak zamanla tadilata uğradığı anlaşılmaktadır. Altıncı bölüm, esas itibariyle batı yandaki bu kütlenin güneydoğu köşesine yerleşik, kendi içerisinde üç bölümlü bir düzenlemeye sahip olan helâ ünitesidir. Helânın güney duvarındaki girişi sağlayan basık kemerli açıklık daha önce de belirttiğimiz gibi sonraki müdahalelerde değiştirilerek bir pencere ve dar bir kapı açıklığına dönüştürülmüștür. Ayrıca bunun doğu yanında üst seviyede küçük bir pencere açıklığı daha bulunmaktadır.

Eski fotoğraflardan (Res.2-3) batıdaki bu kütlenin de genişletildiği açıkça anlaşılmaktadır. Nitekim söz konusu fotoğraflara bakıldığında, ortadaki ana kütleden itibaren güney cephe itibariyle üç büyük açıklık görülmekte ve batı yandaki kütlenin bundan ibaret olduğu anlaşılmaktadır. Ayrıca binanın batı tarafında takriben 10-15 m. mesafe ile başka bir yapı daha görünmekte ve buranın da o dönemdeki ambarı olabileceği düşünülmektedir. Öte yandan, 1970'li yıllara ait fotoğraflarda (Res.4) yapının günümüzdeki görünüşünü yansıttığı ve genişletme çalışmalarının daha önceki dönemlerde gerçekleştirildiği de ortaya çıkmaktadır.

Eserin iç mekân teşekkülünde benzer özellikler mevcuttur. Özellikle bütün kapı ve pencere açıklıkları dış kütle tertibindeki görünüşün aynısını yansıtmaktadır. İç mekâna ait kapılar ise boyuna dikdörtgen basit birer açılıktan ibarettir. Duvarlar çimento harcı ile sıvanarak sarı; tavanlar da ana kütle ile doğudaki kütlede aynı şekilde sıvanarak yüzeylerine beyaz badana yapılmış; zeminler ise kare biçimi fayanslarla kaplanmıştır. Batıdaki ünitenin örtü sistemi ise ahşap malzemeli yarım kırma çatı ile sağlanmıştır. Kapı ve pencere açıklıklarında düz yüzeyli ahşap doğramalar kullanılmış, ayrıca kapı kanatlarının üst kısım doğramaları boyuna dikdörtgen çerçeveler oluşturacak şekilde tasarlanarak camekânla kapatılmıştır. Batı yandaki ambar kısmına ait kapılarda ise enli tahtaların yan yana sıralanması ile büyük birer çift kanat teşkil edilmiş ve açıklığın iç tarafına yerleştirilen iki yana doğru yatay hareket eden raylı bir sistemle açılıp kapanmaları sağlanmıştır (Res.18).

\section{DEĞERLENDİRME}

Modern kentlerin tarihi incelendiğinde büyük bir çoğunluğunun sanayi devrimleri sonucu ortaya çıktığı ve devletlerin endüstri politikaları çerçevesinde hızla geliştiği izlenmektedir. Bu kapsamda Kırıkkale'nin pek çok fabrika ile birlikte konumuzu teşkil eden gar binasının da inşasıyla tamamen bir sanayi şehri olarak doğduğu ve hızlı bir kentleşme gösterdiği 
söylenebilir. Şehrin kuruluşundaki ana etken kuşkusuz ki ülkemizin savunma sanayiinin temelini teşkil eden MKE Kurumu fabrikalarının inşasıdır. Kırıkkale Tren Garı daha önce bahsettiğimiz fabrikalardan kısa bir süre önce, 1925 yılında bir ara istasyon niteliğinde inşa edilmiş ve fabrikalara malzeme teminatı, üretim sürecinin yönetimi, silah ve mühimmat yanı sıra her türlü yiyecek-giyecek eşyası, gübre ve kömür sevkiyatı gibi fonksiyonlar bu istasyon üzerinden yürütülmüştür. Şehir öncelikli olarak bu çevrede kurulmuş (Res.2-4), fabrika personeli ve işçileri ile demiryolu personeli lojmanlarından oluşan bölge İstasyon ve Fabrikalar Mahallesi adını almıştır ${ }^{33}$. İstasyon ve fabrikalar, Kırıkkale’yi çevresine nazaran önemli bir merkez haline getirmiş, çok çeşitli yerlerden işçi ve göç akınına sebep olmuştur $^{34}$. Halen Fabrika Mahallesi adıyla anılan bölge kurulduğu yıllarda kırsal bir görünüş sergilemekte iken şehir geliştikçe kırsal karakterden uzaklaşmaya başlamış ve zamanla yetersiz kalması üzerine etrafında pek çok yeni mahalle oluşmuştur ${ }^{35}$. Nitekim 1931-1945 yılları arasında Yenidoğan, Ovacık, Hüseyin Kahya, Tepebaşı, Gürler ve Kurtuluş Mahalleleri kurulmuş; nüfusun hızla artması sonucu 1945-1955 yılları arasında da Yaylacık, Çallıöz, Güzeltepe, Kaletepe ve Sanayi Mahalleleri ortaya çıkmıştır³.

Demiryolları, o dönemlerin en önemli ulaşım aracı idi ve özellikle sanayi bölgelerinde tesis edilen istasyonlar ana arter olarak şehrin kalbi niteliğini teşkil ediyordu. Kırıkkale Tren Garı’nın da aynı fonksiyonu üstlendiği gözlenmektedir. Halen dahi faaliyetine devam eden fabrikalar yanı sıra Kırıkkale İl Emniyet Müdürlüğü, Kırıkkale Belediyesi, Kırıkkale Adalet Sarayı ve eğitim yapıları gibi şehrin en önde gelen resmî binaları da gar çevresine yakın konumdadır. Hatta eski hastaneler de yine aynı bölgede yer almakta idi. Dolayısı ile istasyon tesisinin şehrin kuruluşu ve gelişimine büyük bir katkı sağladığı anlaşılmaktadır.

Tarihsel, ekonomik ve politik ortam değerlendirildiğinde demiryolu hattı üzerinde yer alan yolcu binalarının, bulundukları coğrafyanın askerî ve ticarî önemlerine göre inşa edildiği, gar binası, ambar, depo ve konaklama birimi gibi muhtelif ünitelerin plan ve projelerinin asker ve mal taşıma kapasitesine göre tasarlandığ $1^{37}$ görülmektedir.

Kırıkkale gar binası, birbirine bitişik üç kütle halinde doğu-batı yönünde dikdörtgen planla uzanır. Duvarlar, kaba yonu-kesme taş kullanılarak yığma tekniği ile örülmüş ve bütün yüzey sıvanarak üzerine de sarı badana yapılmıştır. Örtü sisteminde hepsi Marsilya tipi kiremit kaplı olmak üzere kırma çatı kullanılmıştır. İç mekân itibariyle batı kütle ahşap malzemeli kırma çatıya sahip iken diğer bölümler betonarme düz tavanlıdır. Ortadaki ana kütle yandakilere göre iki katlı ve daha hâkim olarak tasarlanmıştır. Alt kat idarî

33-Köksal, a.g.m., s.171; Atalay, a.g.e., s.62-65, 82.

34-Atalay, a.g.e., s.71-79, 156. Bu cihette Kırıkkale’ye gelerek yerleşen ve uzun yıllar Kuvvet Merkezi’nde işçi olarak hizmet veren ve işe gelip giderken yine bu istasyonu kullanan merhum babam Zekeriyya Çerkez'i rahmet, saygı ve şükranla anıyorum.

35-Köksal, a.g.m., s.171; Vural, a.g.t., s.49-50.

36-Köksal, a.g.m., s.171

37-Sercan Özgencil Yıldırım, “Anadolu ve Bağdat-C.F.O.A-ve Bağdat-Halep-Nusaybin -B.A.N.P Demiryolu Şirketleri Yolcu Binaları Tip Projeler”, Beykent University Jour-nal of Science and Engıneering, S,5, Ankara 2012, s.75. 
büro, güvenlik odası ve dinlenme mekânlarından, üst kat ise lojmandan müteşekkildir. Batısında yükleme merkezi olarak da kullanılmış ambar, elektrik odası, helâ; doğusunda hareket memurluğu, gișe, bekleme salonu ve yine idarî bürolar mevcuttur.

Anadolu demiryolları üzerindeki istasyonların önemli bir kısmının Almanlar tarafından tesis edildiği bilinmektedir. 1890 yılına ait bir belgeye göre Almanların inşa ettikleri istasyonları dört sınıfa ayırdıkları anlaşılmaktadır ${ }^{38}$. Bu kapsamda Kırıkkale Tren Garı, her ne kadar Türk mühendisler tarafından inşa edilmiş olsa da tipoloji itibariyle Almanların 3. tip istasyon planına benzeyen giriş bölümü iki, yan bölümleri tek katlı garlar sınıfınd ${ }^{39}$ değerlendirilebilir. Genellikle önemli istasyonlarda tercih edilen ${ }^{40}$ bu tipte ortadaki ana kütleler iki, yan kütleler tek katlıdır. Ana kütlenin ikinci katı hepsinde de lojman olarak kullanılmıştır ve önünde çoğunlukla bir balkon veya sundurma yer alır. $\mathrm{Bu}$ tarz uygulamanın benzerlerine Anadolu'da Cumhuriyet döneminde inşa edilmiş pek çok istasyonda rastlamak mümkündür. Nitekim yakın bölgedeki Irmak (Kırıkkale), Şefaatli (Yozgat)ve Kalecik (Ankara) ile birlikte Çankırı, Çerkeş (Çankırı), Çatalağzı (Zonguldak), İsmetpaşa (Karabük), Karabük, Niğde, Bor (Niğde) ve Şarkışla (Sivas) tren garlar1 ${ }^{41}$ plan, malzeme, kütle, cephe tasarımı ve örtü sistemi bakımından çok yakın benzerlikler sergilemektedir. Ayrıca bunlar arasında Karabük istasyonu ambar kütlesinin de Kırıkkale'dekine benzer şekilde sonradan genişletildiğ ${ }^{42}$ anlaşılmaktadır.

Kırıkkale Tren Garı’nda ana kütle ile doğu yandaki kütlenin kapı ve pencere açıklıklarında sivri kemerli, batıdaki ambar ünitesinde ise basık kemerli bir düzenleme uygulanmıştır. Ayrıca kapı ve pencere açıklıklarına ait kemer ve söve taşları ile duvar köşe bağlantısındaki taşlar yüzeyden kısmen taşırılarak vurgulanmış, kemer kenarları yine kısmî taşıntılı profilli silmelerle çerçevelenmiş, kemer üzengileri hizasınca uzanan kornişlerle birlikte saçak silmeleri kullanılmış ve böylelikle cephelere önemli bir hareketlilik kazandırılmıştır. Yukarıda sıralanan garların hepsinde de görülen bu cephe tasarımının benzerlerine Cumhuriyet döneminde inşa edilen pek çok yapıda rastlanmakta ve dolayısı ile bu uygulama dönemin genel bir özelliği olarak karşımıza çıkmaktadır. Yine Kırıkkale’ye bağlı Kılıçlar, Yahşihan ve Çerikli garları ile çok yakın çevredeki Lalahan, Elmadağ (Ankara) ve Yerköy (Yozgat) ${ }^{43}$ garları plan, malzeme, kütle ve cephe tasarımı bakımından yakın benzerlikler sergilemekle birlikte, kapı ve pencere açıklıklarında sivri kemer yerine basık kemer kullanılması ve ikinci katlarında balkon veya sundurma gibi unsurların bulunmayışı

38-Haştemoğlu, a.g.t.,s.105.

39-Haştemoğlu, a.g.t., s.114. Sınıflandırma için ayrıca bkz., Mehmet Emin Başar-Hacı Abdullah Erdoğan, "Osmanlı'dan Cumhuriyet'e Türkiye'de Tren Garları”, Selçuk Üniversitesi Mühendislik Mimarlık Fakültesi Dergisi, C.24, S.3, Konya 2009, s.39-41.

40-Haştemoğlu, a.g.t., s.105, 114.

41-Adı geçen eserler hakkında bilgi ve fotoğraf için bkz., Haştemoğlu, a.g.t., s.112-121; Karabük tren garı için ayrıca bkz., Lütfiye Göktaş Kaya, "Karabük Kent Kimliği İçinde İstasyon Binasının Yeri”, XX. Uluslararası Ortaçă̆ ve Türk Dönemi Kazıları ve Sanat Tarihi Araştırmaları Sempozyumu Bildirileri, 2-5 Kasım 2016, C.1, Sakarya 2018, s.504-518.

42-Göktaş Kaya, a.g.m., s.508.

43-Adı geçen eserler hakkında bilgi ve fotoğraf için bkz., Haştemoğlu, a.g.t., s.117-121. 
bakımından da bazı farklılıklar göstermektedir.

Eserde herhangi bir süsleme unsuru da mevcut değildir.

\section{SONUÇ}

Cumhuriyet Dönemi’nde bir sanayi kenti olarak doğan ve bu kapsamda gelişen Kırıkkale, konumu itibariyle Orta Anadolu’nun birbirine bağlanması yanı sıra doğu ve güney bölgeleri ile irtibatında da önemli bir bağlantı noktasıdır. Bu irtibatın sağlanmasında karayolu ile birlikte demiryolunun ve dolayısı ile konumuzu teşkil eden Kırıkkale Tren Garı’nın da önemi büyüktür. Şehrin oluşumundaki en önemli faktör kuşkusuz ki ordunun ihtiyaçlarını gidermesi için kurulan ve savunma sanayiinin temelini teşkil eden MKE Fabrikaları'dr. Ancak burada üretilen her türlü makine, silah, barut ve teçhizatın dağııımı, malzeme temini, çalışanların ve diğer yolcuların ulaşımı, yiyecek, içecek, giyecek, barınma ihtiyaçlarının karşılanması ve her türlü eşyanın getirilip götürülmesi gibi fonksiyonlar dikkate alındığında şehrin kuruluşu ve gelişiminde istasyonun önemi daha da iyi anlaşılmaktadır.

Kırıkkale Tren Garı plan, malzeme, kütle ve cephe tasarımı bakımından bir bütün olarak değerlendirildiğinde, Anadolu Türk mimarisi gelişim çizgisi içerisinde Cumhuriyet dönemi mimarisinin genel karakteristiğini sergileyen bir eser olmasının yanı sıra fabrikalarla birlikte Kırıkkale’ye kent kimliğini kazandıran bir sembol olarak da karşımıza çıkmaktadır. 


\section{KAYNAKÇA}

Altın, Yakup, Bir Cumhuriyet Şehri Kırıkkale, Kırıkkale Valiliği Yayınları, Devran Matbaacilık, Ankara 2002.

Arslan, Mukaddes, "Milli Mücadele Tarihimizde Demiryolları ve Demiryolcular", Cumhuriyet Dönemi Demiryolları Sempozyumu, 18 Aralık 2008, Atatürk Araştırma Merkezi Yayınları, Ankara 2010, s.47-82.

As, Efdal, Cumhuriyet Dönemi Ulaşım Politikaları (1923-1960), (Dokuz Eylül Üniversitesi Atatürk İlkeleri ve İnkılâp Tarihi Enstitüsü yayınlanmamış Doktora Tezi), İzmir 2006.

Aslıyüce, Erdoğan, Her Yönüyle Kırıkkale, Emel Matbaacılık, Ankara 1974. Atalay, Beşir, Sanayileşme ve Sosyal Değişme (Kırıkkale Araştırması), DPT, Ankara 1983.

Başar, Mehmet Emin-Erdoğan, Hacı Abdullah, “Osmanlidan Cumhuriyet’e Türkiye’de

Tren Garları", Selçuk Üniversitesi Mühendislik Mimarlık Fakültesi Dergisi, C.24, S.3,Konya 2009, s.29-44.

Borak, Sadi, "Demiryollarının Tarihi", Hayat Tarih Mecmuası, S.12 (98), 1969, s.82-86. Demir, Ömer-Örsdemir, A.Vural-Altın, Yakup, Her Yönüyle Kırıkkale, Kırıkkale 1997.

Demiryolları Mecmuası, Cumhuriyetin 10. Yılı Özel Sayısı, C.9, S.104/105, 29.X.1933,s.545.

Durak, Selen, “19. Yüzyılda Geniş Açıklıklı Çatı Strüktürlerinin Gelişiminde Demiryolu

İstasyon Binalarının Önemi”, 6. Ulusal Çatı ve Cephe Sempozyumu, Uludağ Üniversitesi Mühendislik ve Mimarlık Fakültesi-Görükle Kampüsü-Bursa, 12-13 Nisan 2012, s.18 .

Engin, Vahdettin, Rumeli Demiryolları, Eren Yayıncılık, İstanbul 1993.

Göktaş Kaya, Lütfiye, "Karabük Kent Kimliği İçinde İstasyon Binasının Yeri”, XX. Uluslararası Ortaçağ ve Türk Dönemi Kazıları ve Sanat Tarihi Araştırmaları Sempozyumu Bildirileri, 2 - 5 Kasım 2016, C.1, Sakarya 2018, s.504-518.

Göre, Serap-Ekici, S.Ebru-Atar, Metin, Kırıkkale Kültür ve Turizm Envanteri, Kırıkkale Valiliği Yayınları, Kırıkkale 2013.

Haştemoğlu, Hasan Şehmuz, Demiryolu İstasyon Binalarına Yeni Fonksiyon Önerileri Geliştirilmesi (Süleyman Demirel Üniversitesi Fen Bilimleri Enstitüsü İnşaat Mühendisliği Anabilim Dalı yayınlanmamış Doktora Tezi), Isparta 2012.

Hülagü, Metin, “Cumhuriyet Öncesi Osmanlı Demiryollarına Genel Bir Bakış”, Cumhuriyet 
Döneminde Demiryolları Sempozyumu, 18 Aralık 2008, Atatürk Araştırma Merkezi Yayınları, Ankara 2010, s.25-45.

Kankal, A., "Kırıkkale Tarihine Dair Araştırmalar I: İskân”, Osmanlı Tarihi AraştırmalarıMerkezi Dergisi (OTAM), S.9, Ankara 1998, s.225-239.

Kırıkkale İl Yıllı̆̆ı, Kırıkkale Valiliği Yayını, 1999.

Köksal, Aydoğan, “Kızılırmak Doğusunda Ankara’nın Üç İlçe Merkezi”, Ankara Üniversitesi DTCF Coğrafya Araştırmaları Dergisi, Sayı:3, Ankara 1962, s.169-186.

Özdemir, Mehmet, “Tren Gelir, Hoş Gelir, Kara Trenin Hikâyesi”, Anatolia: Turizm Araştırmaları Dergisi, C.23, S.1, 2012, s.117-123.

Özgencil Yıldırım, Sercan, “Anadolu ve Bağdat-C.F.O.A-ve Bağdat-Halep-Nusaybin

-B.A.N.P Demiryolu Şirketleri Yolcu Binaları Tip Projeler", Beykent University Journal of Science and Engineering, S,5, Ankara 2012, s.69-93.

Özgür, Damla, Kırıkkale’de Türk Devri Mimari Eserleri (Gazi Üniversitesi Sosyal Bilimler Enstitüsü Sanat Tarihi Anabilim Dalı yayınlanmamış Yüksek Lisans Tezi), Ankara 2019.

Özyüksel, Murat, Osmanl İmparatorluğunda Nüfuz Mücadelesi, Anadolu ve Bağdat Demiryolları, Türkiye İş Bankası Kültür Yayınları, İstanbul 2013.

Pehlivanlı, Mehmet, Kırıkkale Çevre İncelemesi, Cemiloğlu Yayınları, Ankara 1986.

Pehlivanlı, Mehmet, Kırıkkale, Genişletilmiş II. Baskı, Ankara 1992.

Saluk, Yağmur, Kırıkkale-Keskin’in Kültür Mirası Orta Anadolu'da Bir Belgeleme ve Koruma Çalışması, Literatür Yayınları, İstanbul 2016.

Tarih İçinde Kırıkkale, Kırıkkale Belediyesi Yayınları, Kırıkkale 2008

Tosun, Elif, Kırıkkale Keskin İlçesindeki Türk Mimari Eserleri (Ankara Hacı Bayram Veli Üniversitesi Sosyal Bilimler Enstitüsü Sanat Tarihi Anabilim Dalı yayınlanmamış Yüksek Lisans Tezi), Ankara 2019.

Uçar, Oğuz, 1923-1933 Yıllarında T.C. Devleti Demiryolları Politikası (Ankara Üniversitesi Türk İnkılap Tarihi Enstitüsü yayınlanmamış Yüksek Lisans Tezi), Ankara 1989.

Vural, Ercan, Kırıkkale Şehrinin Cumhuriyetten Günümüze Mekânsal Gelişimi (İstanbul Üniversitesi Sosyal Bilimler Enstitüsü Coğrafya Anabilim Dalı yayınlanmamış Yüksek Lisans Tezi), İstanbul 2018. 
Yıldırım, İsmail, Cumhuriyet Döneminde Demiryolları, Atatürk Araştırma Merkezi Yayınları, Ankara 2001.

Yıldırım, Mecit, Tarihte Kırıkkale, Öğretmenler Matbaası, Ankara 1966.

Yücel, Serhan-Taşar, Murat, "Demiryolunun Stratejik Önemi ve Erken Cumhuriyet Döneminde Demiryolu Siyaseti”, Vakanüvis-Uluslararası Tarih Araştırmaları Dergisi/ International Journal of Historical Researches, Y.1,No.1, Mart 2016, s.293-342.

http://www.kirikkale.gov.tr/tarihce (E. T. 02.05.2020).

https://www.mkek.gov.tr/tr/page.aspx?id=13 (E. T. 21.03.2020).

https://www.bitmezat.com/urun/1260325/kirikkale-tren-gari (E.T.14.04.2020).

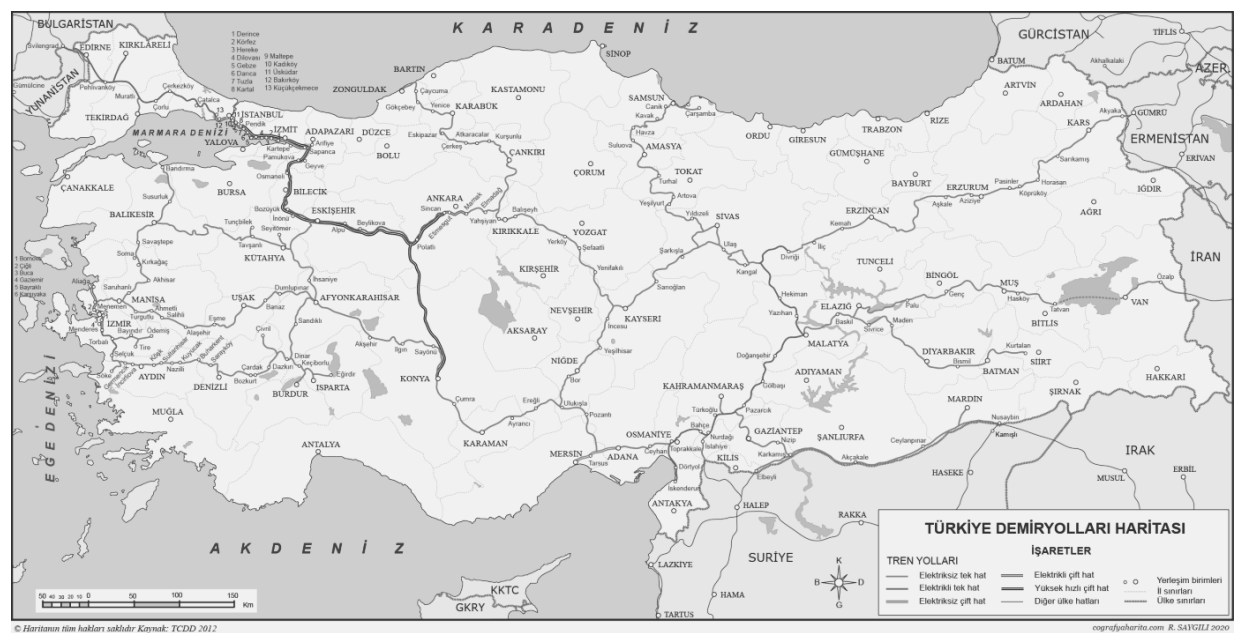

Kaynak: http://cografyaharita.com/haritalarim/4hturkiye-demiryollari-haritasi2.png(E.T. 02.05.2020).

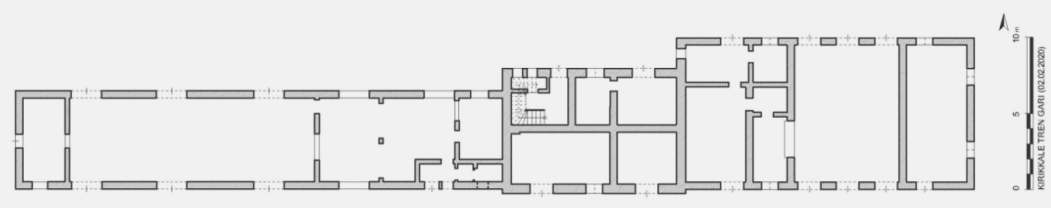

Kaynak: (Rölöve-Çizim: Murat Çerkez) 
Resim 1. Kırıkkale Tren Garı, Güneydoğudan Genel Görünüş..

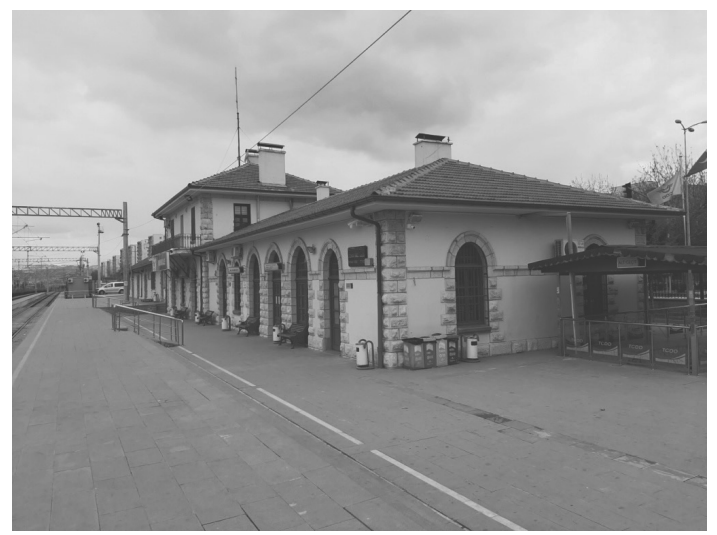

\section{Resim2. Kırıkkale Tren Garı, İnşa edildiği Yıllardaki Durumu.}

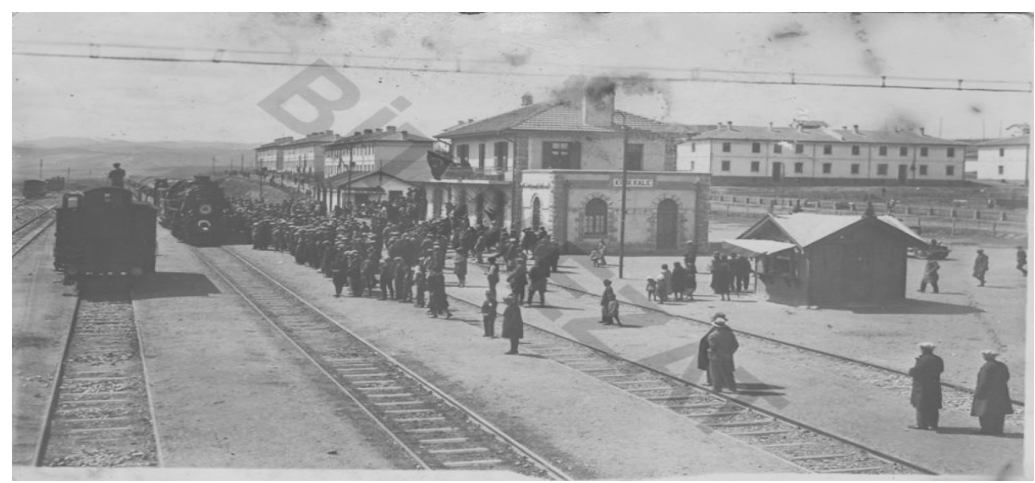

Kaynak: https://www.bitmezat.com/urun/1260325/kirikkale-tren-gari (E.T.14.04.2020). 


\section{Resim 3. Kırıkkale Tren Garı, Güneyden Görünüş}

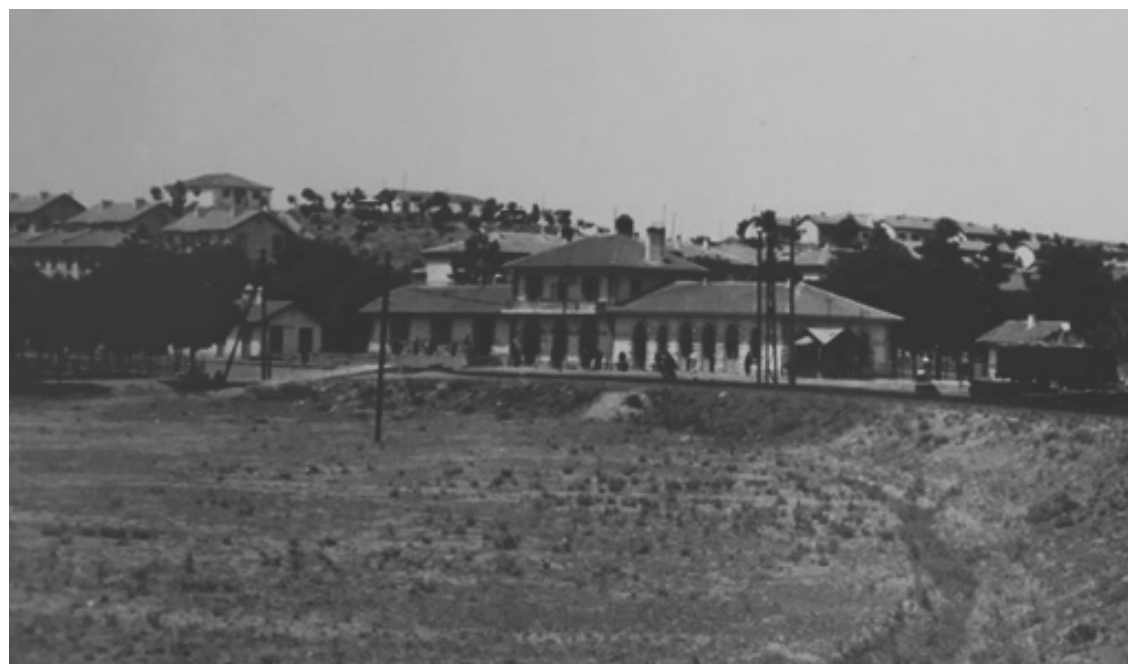

Kaynak: (A. Yaman Arşivi’nden).

Resim 4. Kırıkkale Tren Garı, 1970'li Yıllardaki Durumu

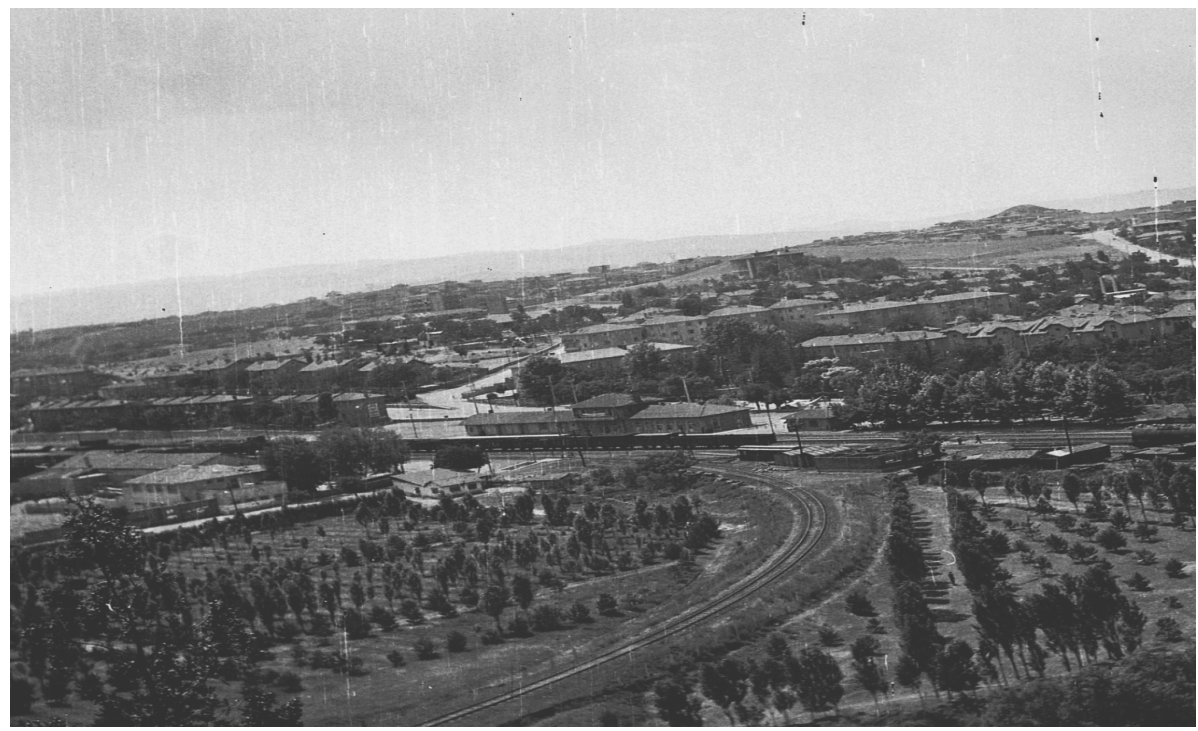

Kaynak: (A. Yaman Arşivi'nden). 
Resim 5. Kırıkkale Tren Garı, Ana Kütle Güney Cephesi.

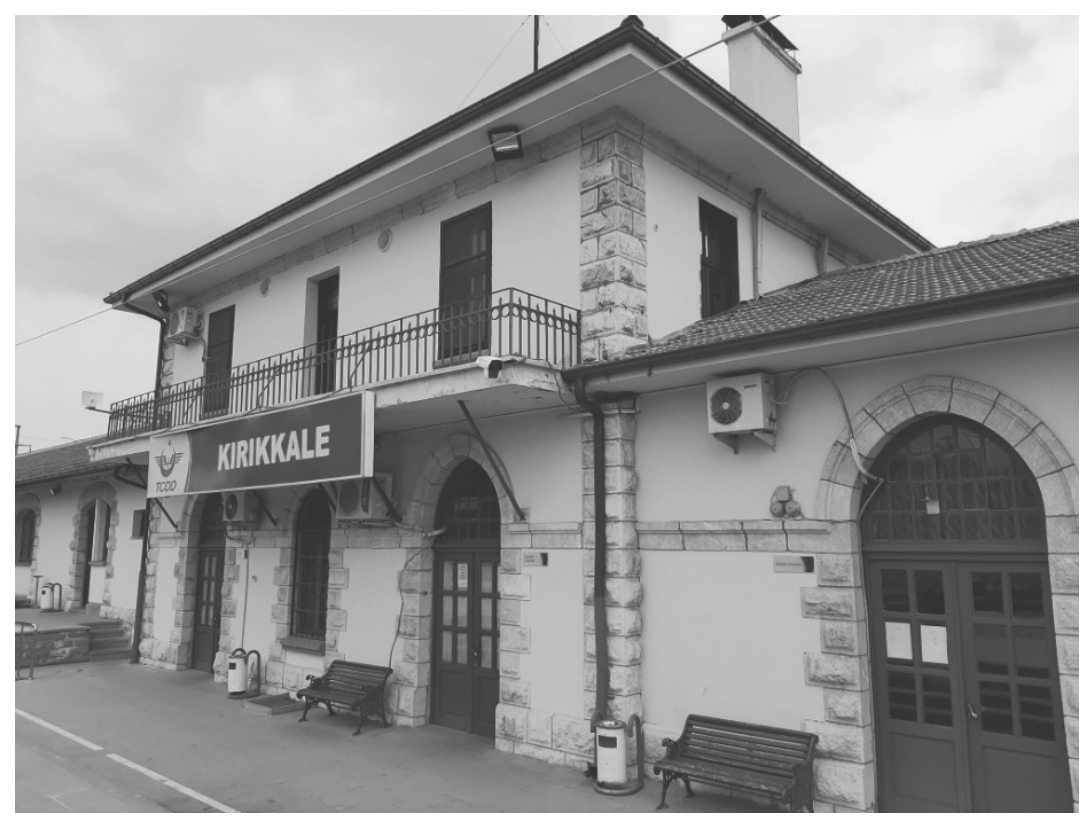

Resim 6. Kırıkkale Tren Garı, Kapı ve Pencere Açıklıkları

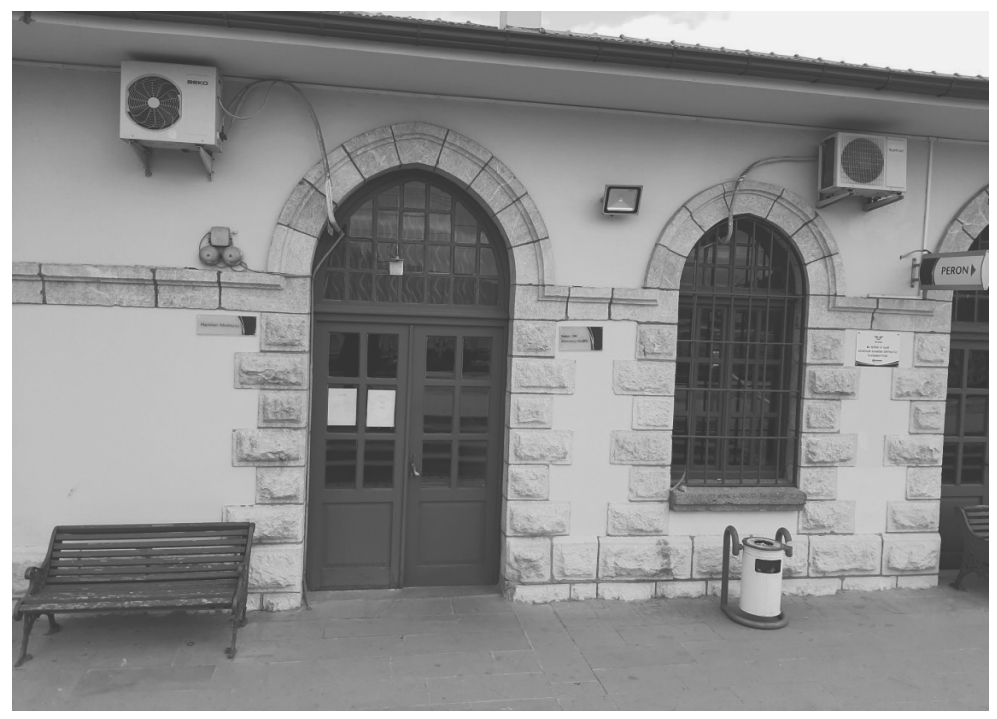




\section{Resim 7. Kırıkkale Tren Garı, Ana Kütle Kuzey Cephesi.}

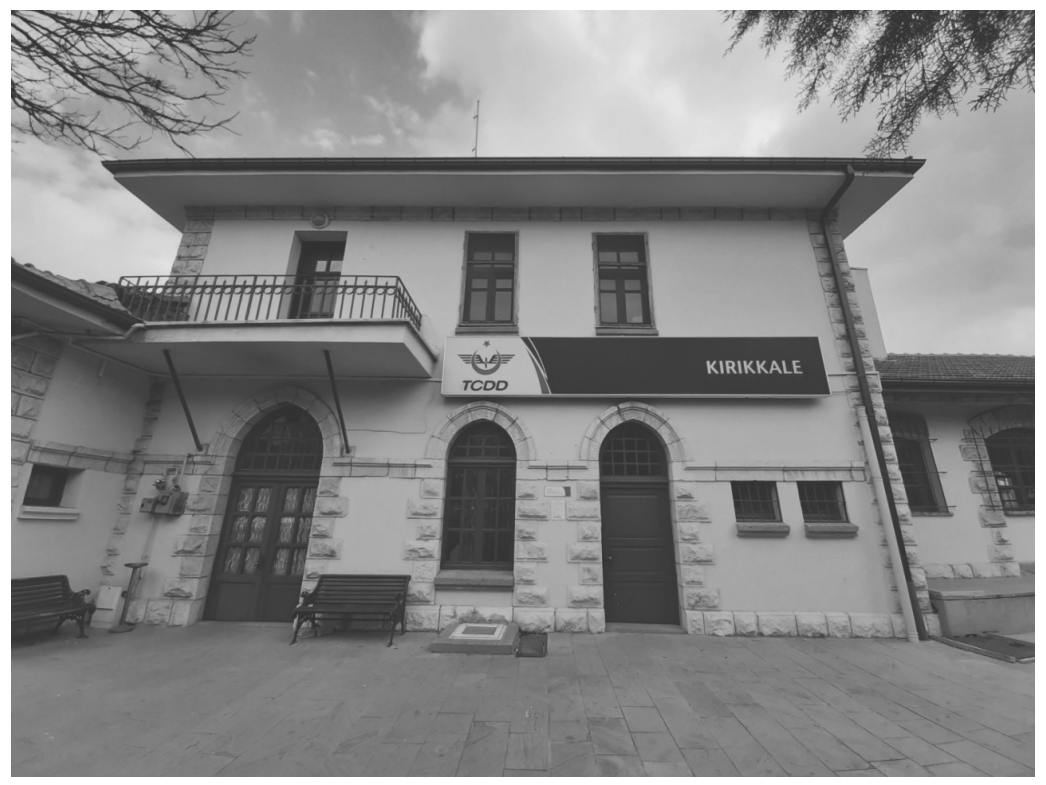

Resim 8. Kırıkale Tren Garı, Doğu Kütle Kuzey Cephesi.

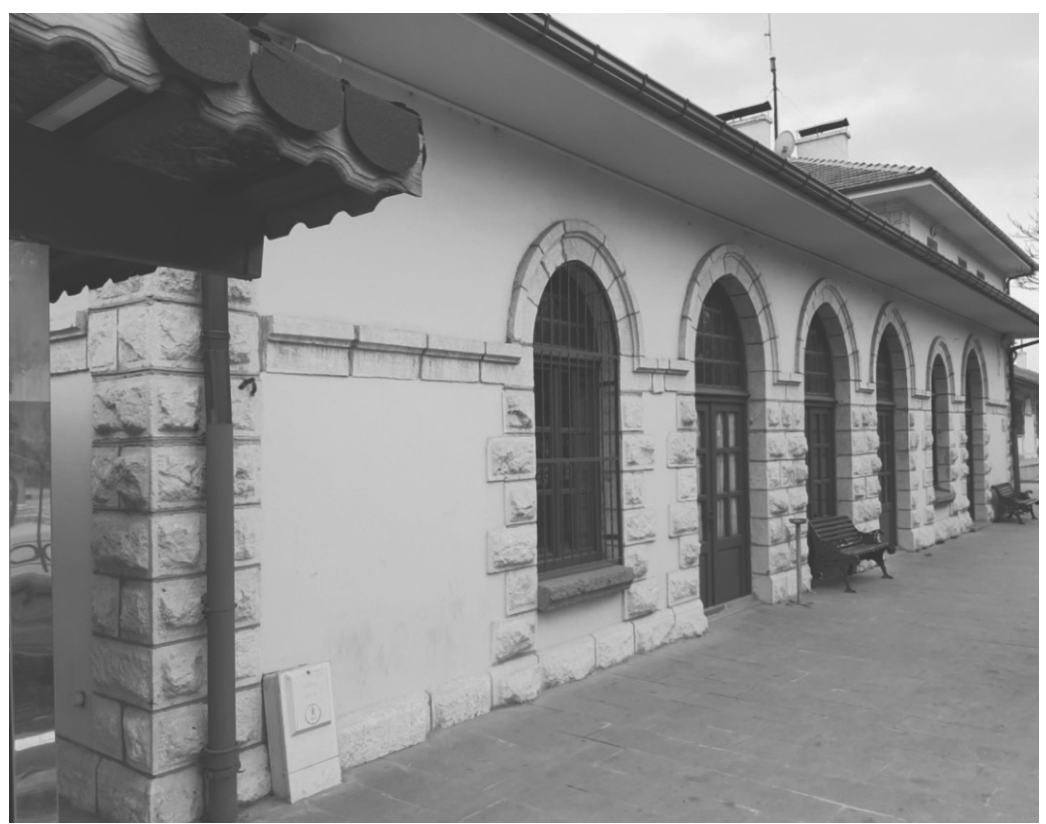


Resim 9. Kırıkkale Tren Garı, Batı Kütle Kuzey ve Batı Cepheleri.

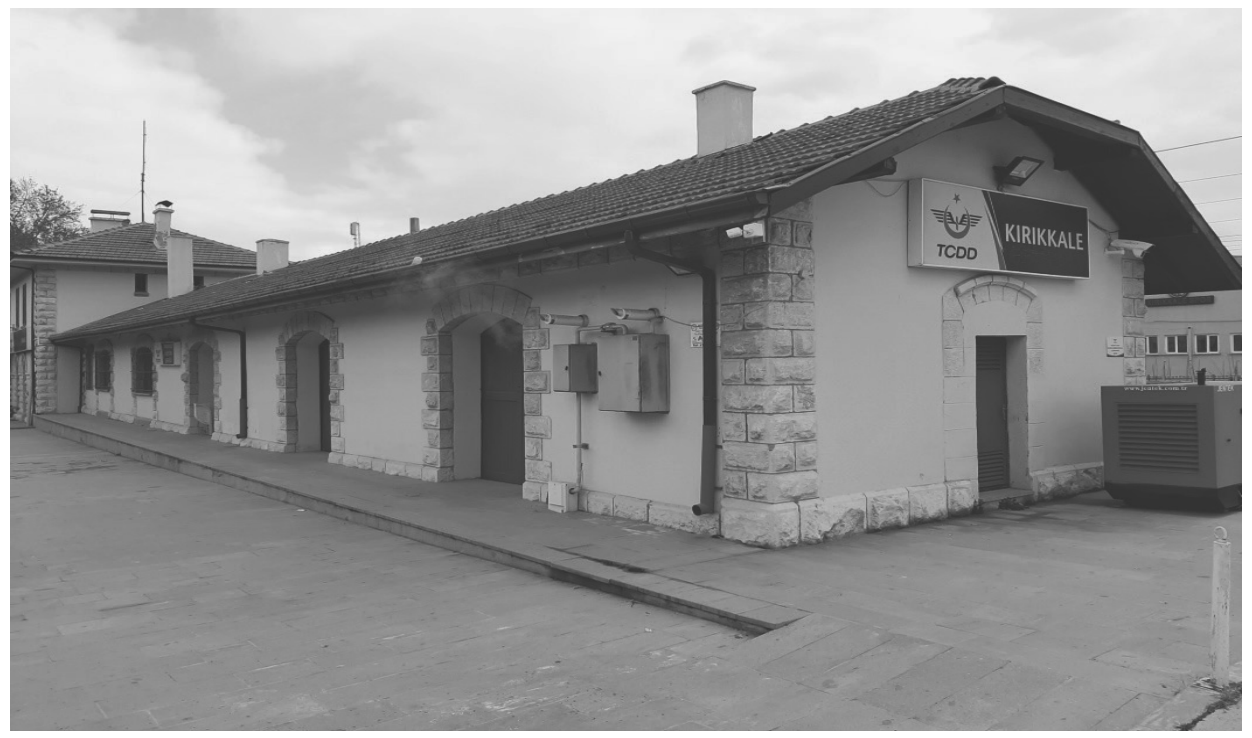

Resim 10. Kırıkkale Tren Garı, Batı Kütle Güney Cephesi.

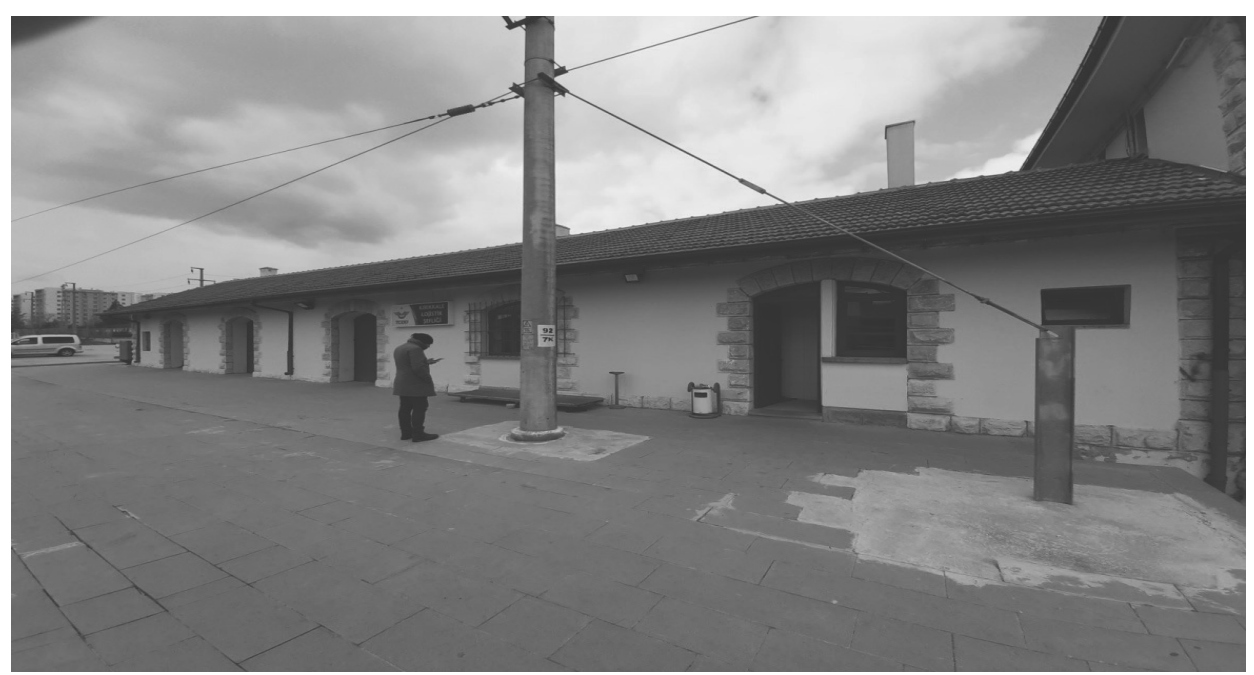


Resim 11. Müdür Yardımcısı Odasına Doğudan Bakış.

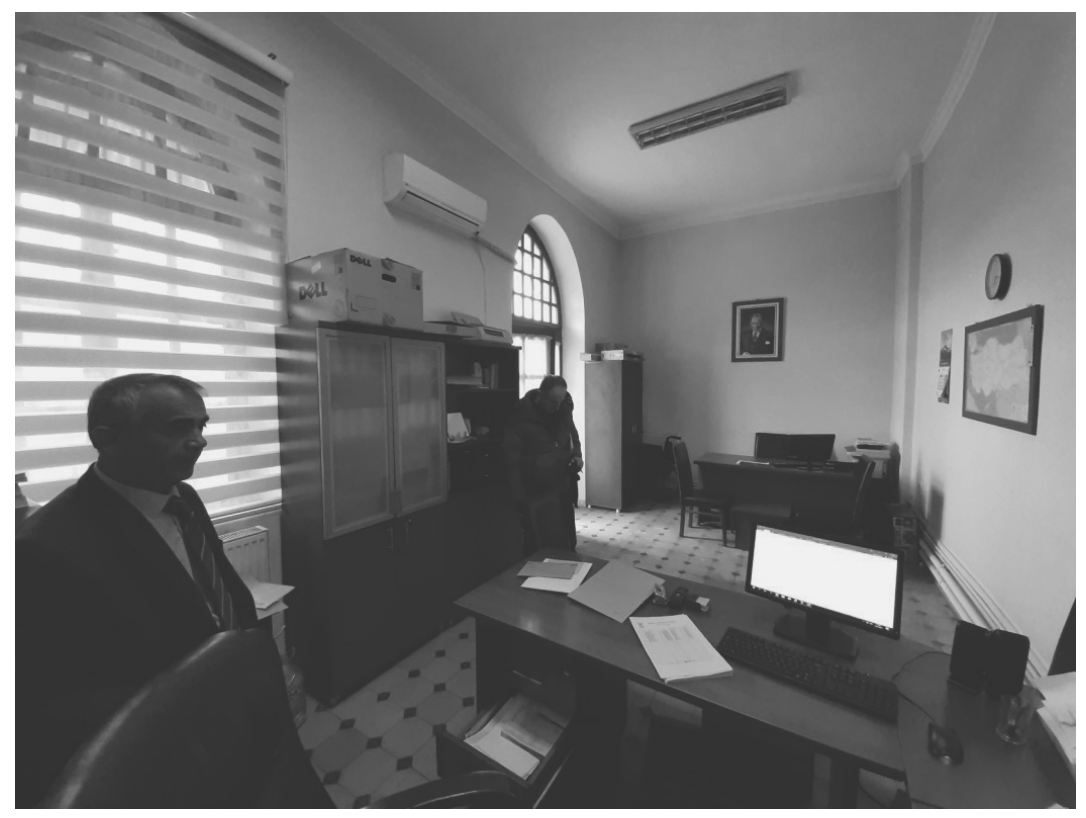

Resim 12. Kırıkkale Tren Garı, Lojman Merdivenleri.

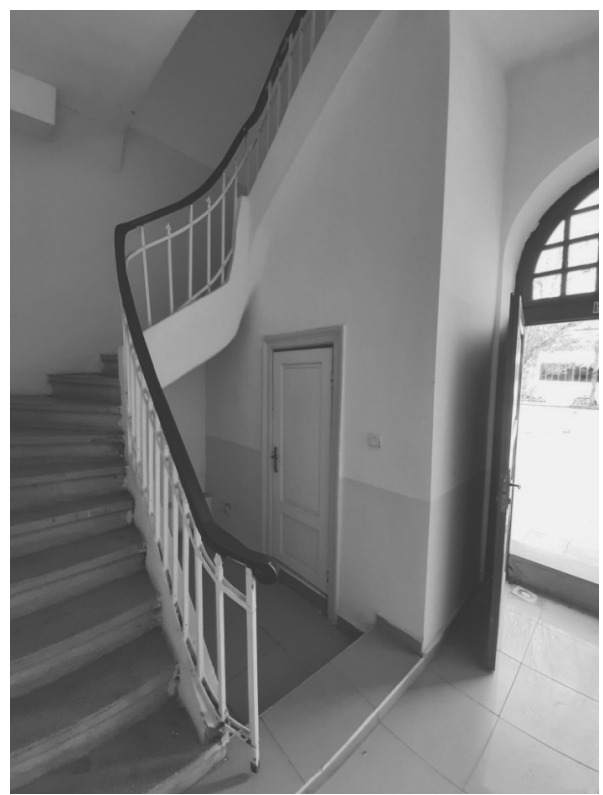

Kırıkkale Tren Garı Üzerine Bazı Tespitler 
Resim 13. Kırıkkale Tren Garı, Lojmandan görünüş.

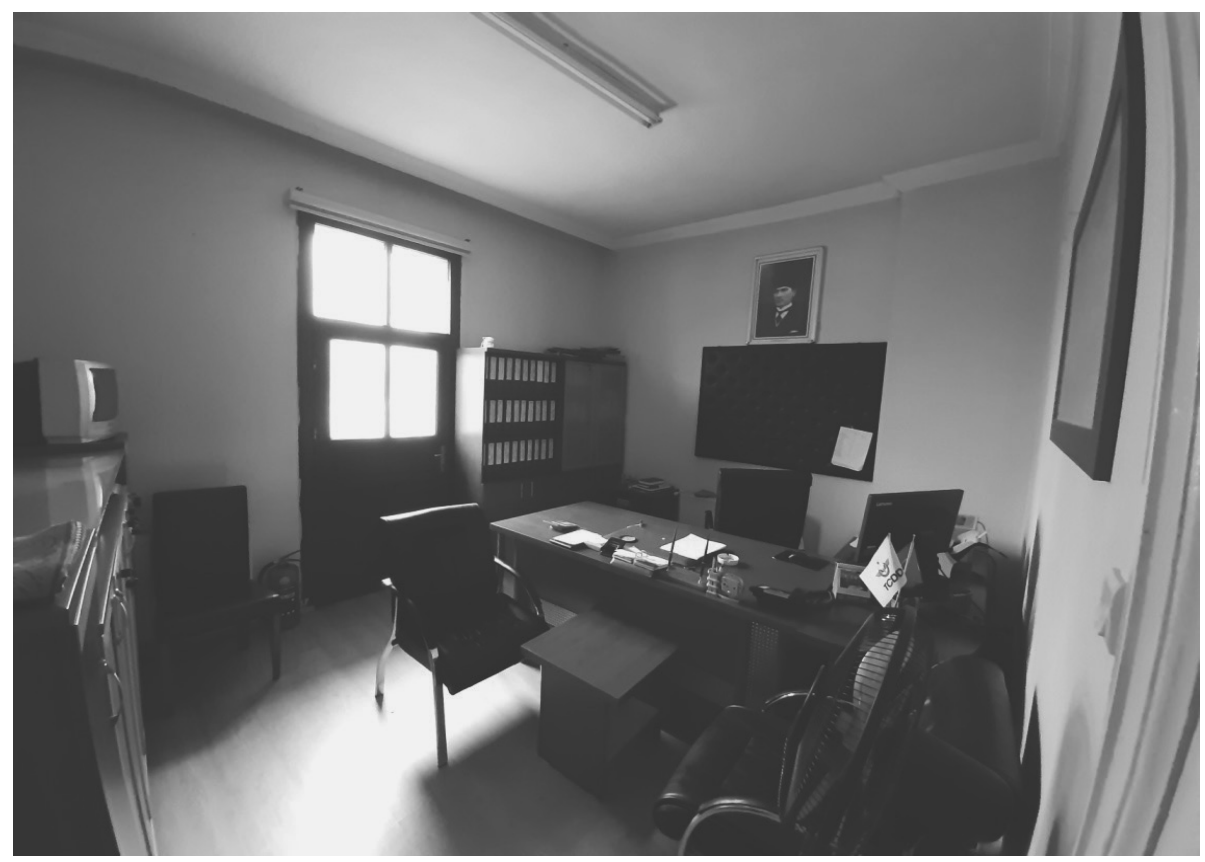

Resim 14. Kırıkkale Tren Garı, Dinlenme Odası

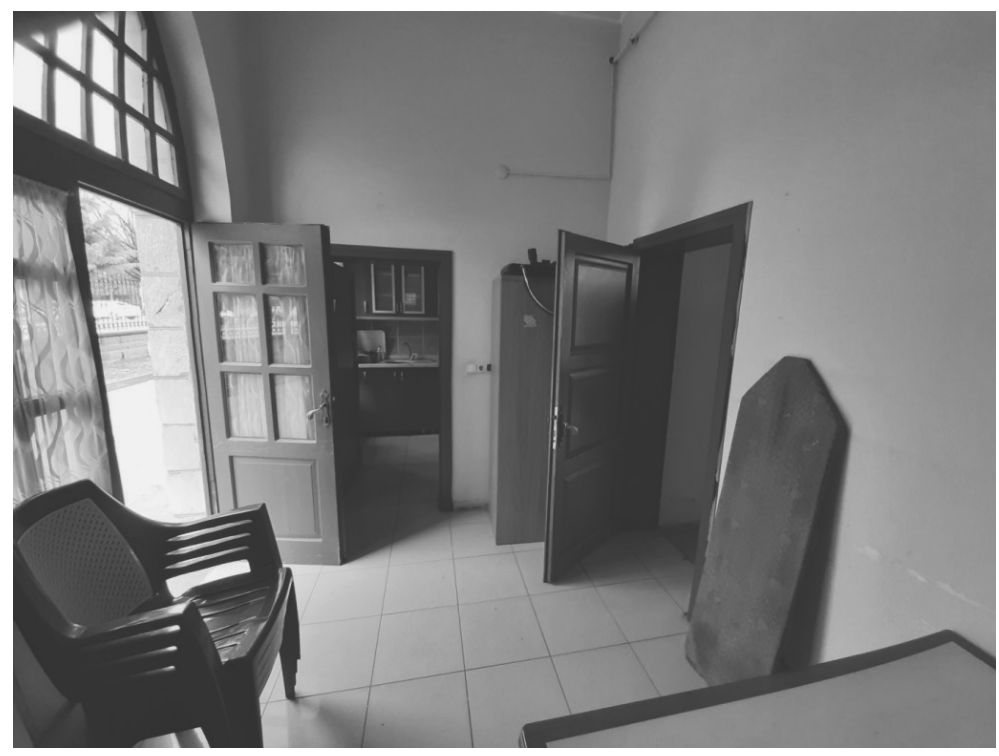


Resim 15. Kırıkkale Tren Garı, Hareket Memurluğu Ünitesi.

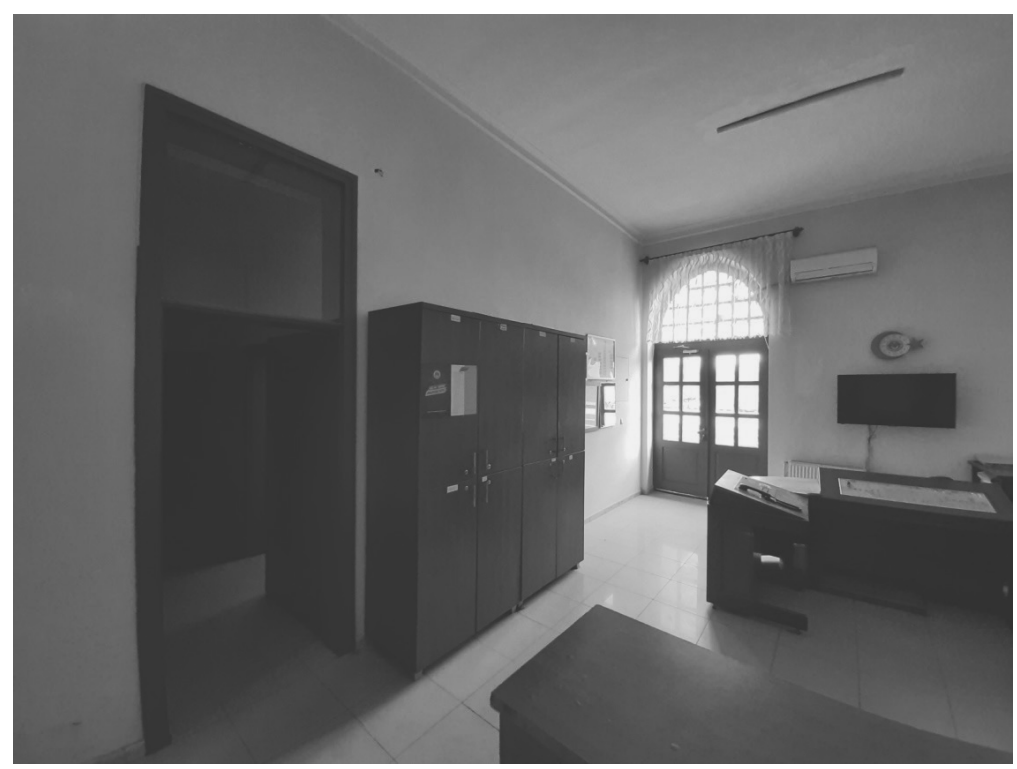

\section{Resim 16. Bekleme Salonuna Güneydoğudan Bakış.}

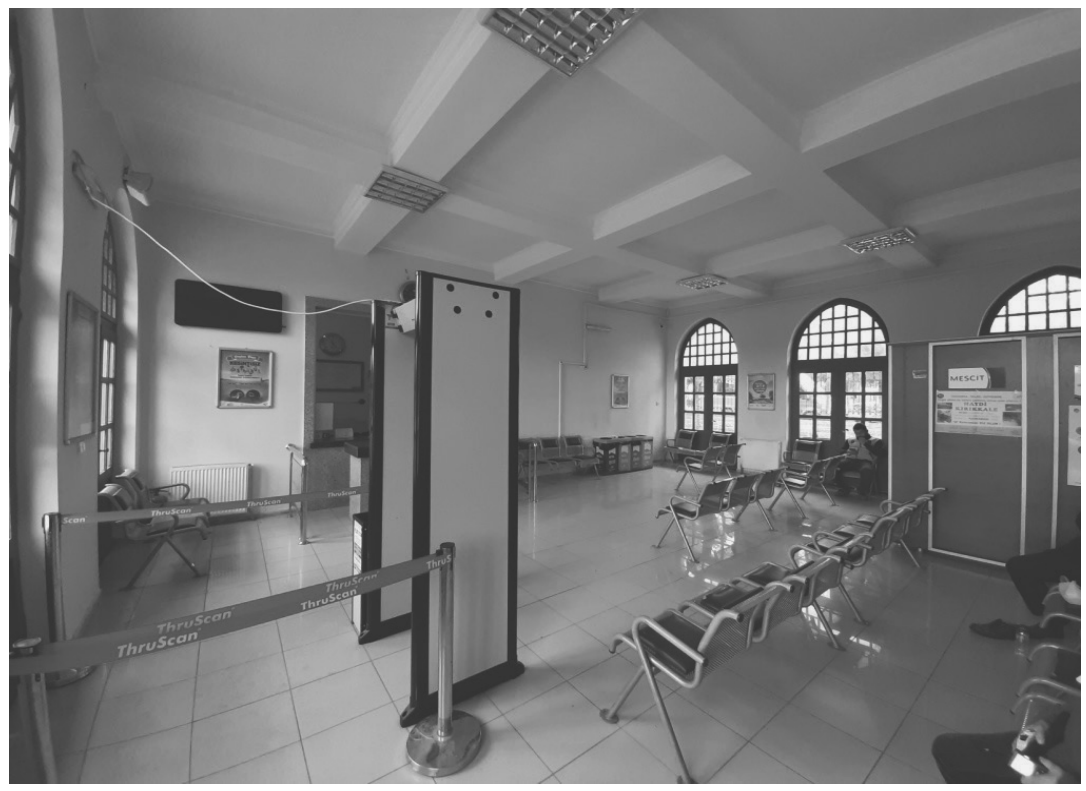


Resim 17. Güneybatıdan Bakışla Gar Müdürlüğü.

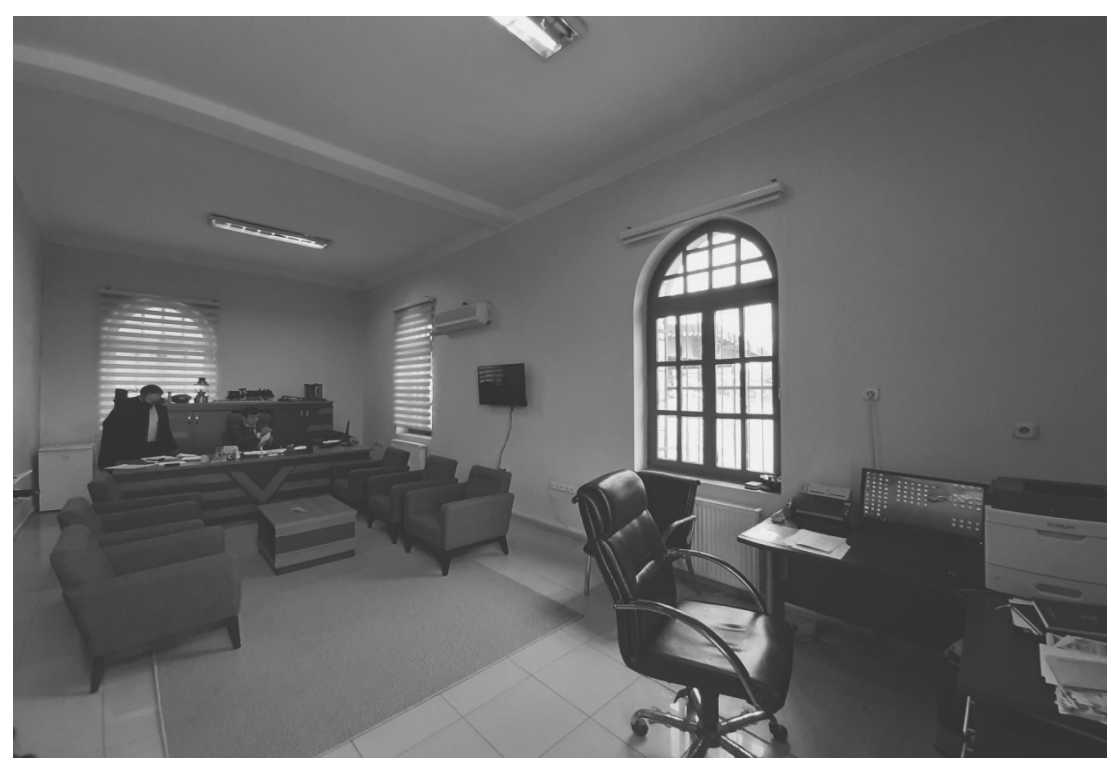

Resim 18. Ambar Ünitesine Batıdan Bakış.

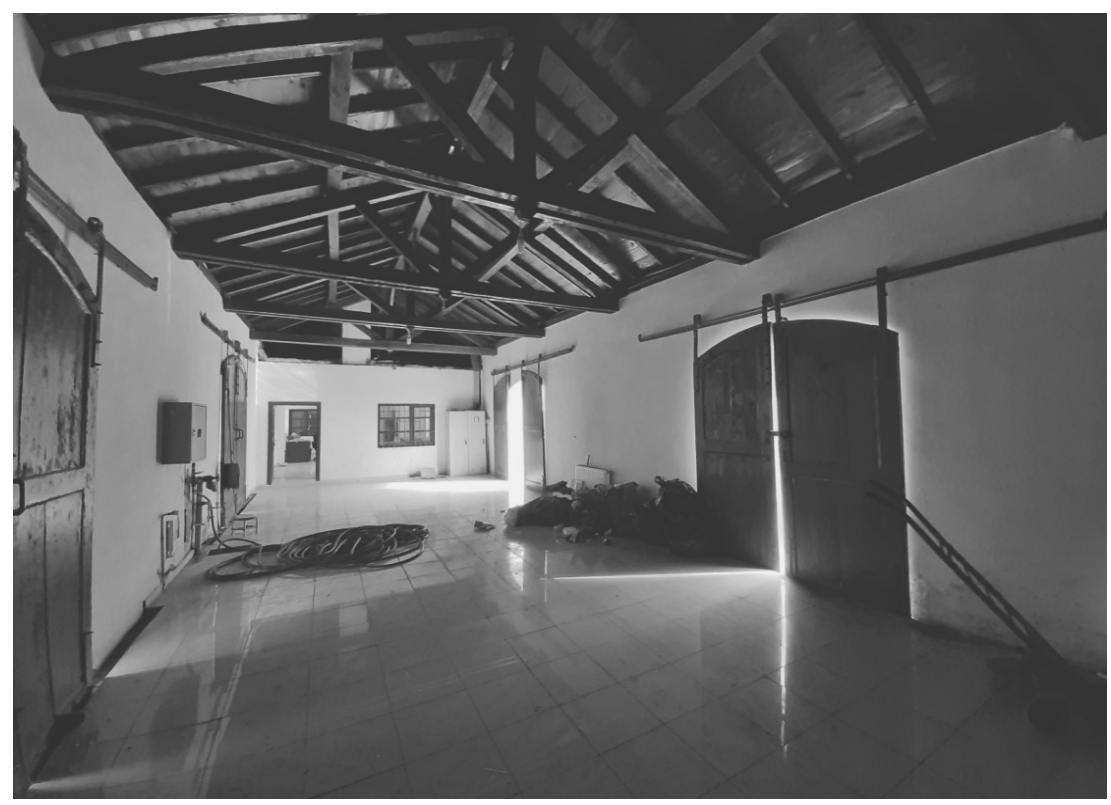


Resim 19. Batı Kütle, Üçüncü ve Dördüncü Üniteler.

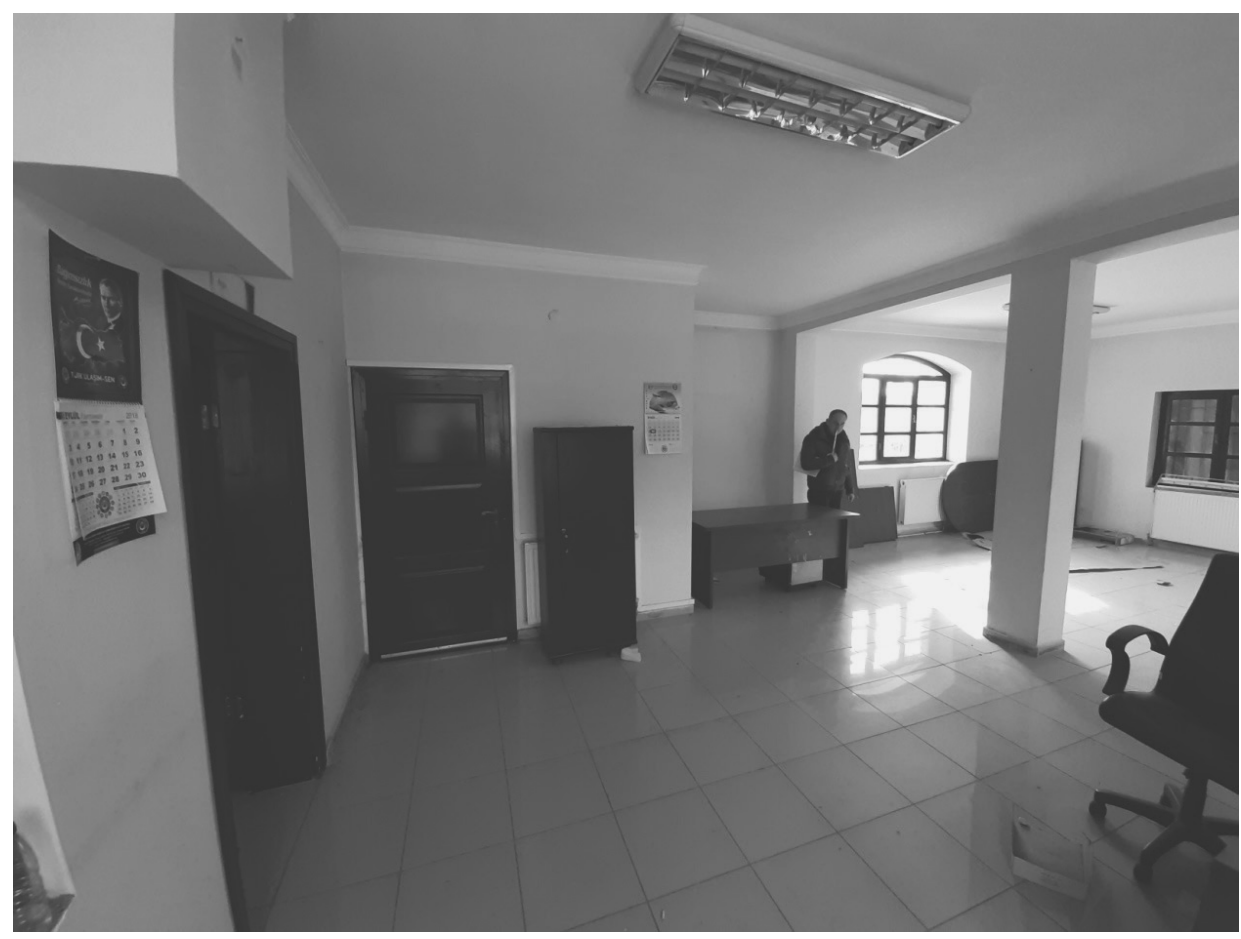


